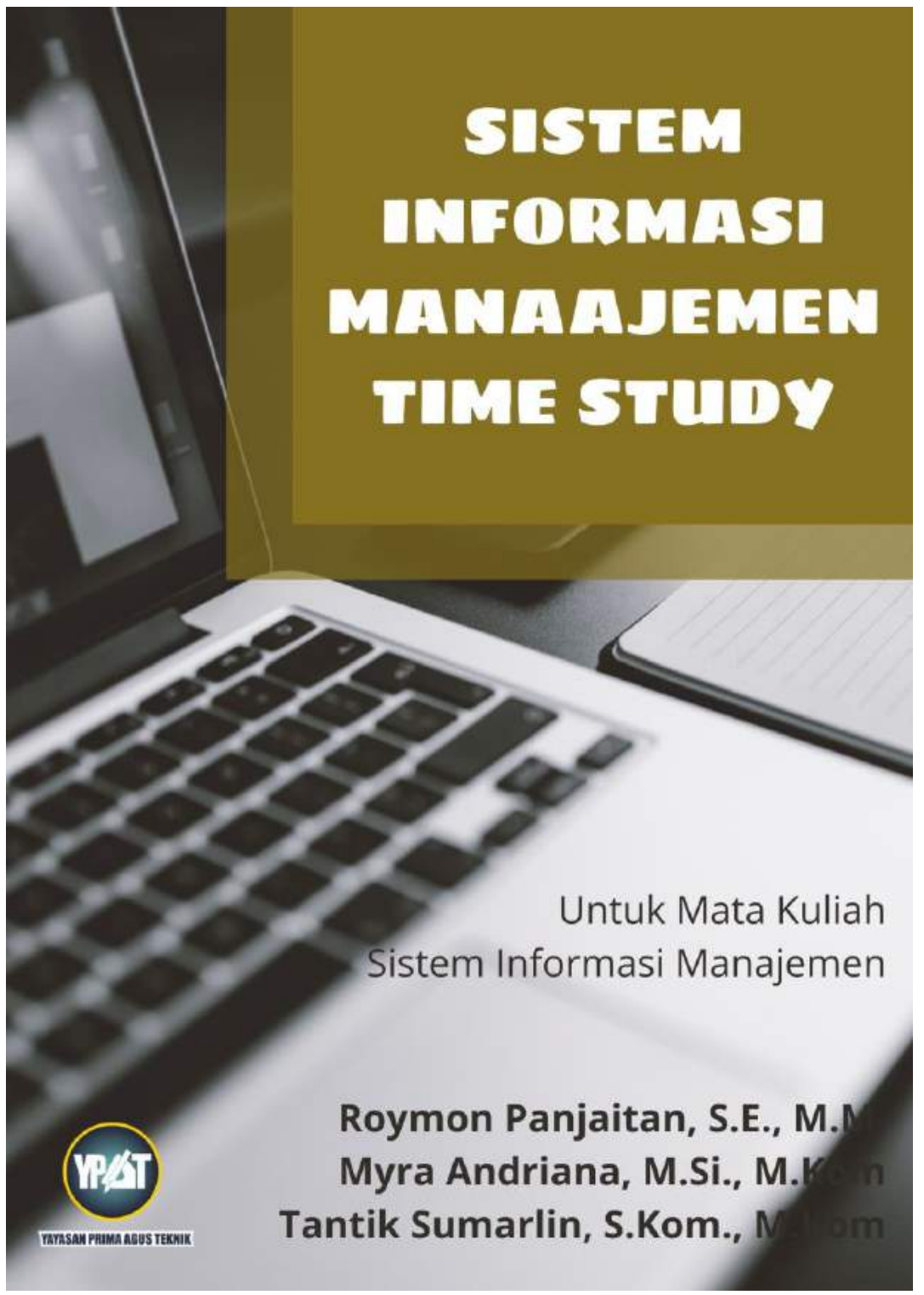




\title{
Sistem Informasi Manajemen Time Study
}

\author{
Oleh : \\ Roymon Panjaitan, S.E., M.M. \\ Tantik Sumarlin, S.Kom., M.Si \\ Myra Andriana, M.Si., M.Kom.
}

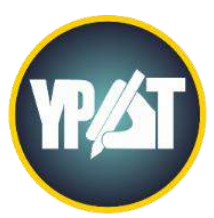

YAYASAN PRIMA AGUS TEKNIK 


\section{Sistem Informasi Manajemen Time Study}

Penulis:

- Roymon Panjaitan, S.E., M.M.

- Tantik Sumarlin, S.Kom., M.Si

- Myra Andriana, M.Si., M.Kom.

ISBN : 9786235734118

Editor:

Edwin Zusrony, M.M., M.Kom.

Penyunting :

Zaenal Mustofa, S.Kom.,M. Kom

Desain Sampul dan Tata Letak :

Hendri Rasminto, S.Kom.,M.Si

\section{Penerbit :}

Yayasan Prima Agus Teknik

Redaksi: Jln Majapahit No 605 Semarang

Tlpn. (024) 6723456

Fax . 024-6710144

Email: penerbit_ypat@stekom.ac.id

\section{Distributor Tunggal:}

UNIVERSITAS STEKOM

Jln Majapahit No 605 Semarang

Tlpn. (024) 6723456

Fax . 024-6710144

Email: info@stekom.ac.id

Hak Cipta dilindungi Undang undang

Dilarang memperbanyak karya Tulis ini dalam bentuk dan dengan cara apapun tanpa ijin tertulis dan penerbit. 


\section{HALAMAN PENGESAHAN}

Judul Buku Ajar

Study

Mata Kuliah

Nama Penulis

NIDN

Progdi

Fakultas

Unit

Komputer
: Sistem Informasi Manajemen Time

: Sistem Informasi Manajemen

: - Roymon Panjaitan, S.E., M.M.

- Tantik Sumarlin, S.Kom., M.Si

- Myra Andriana, M.Si., M.Kom.

: -0615108103

$-0618027502$

$-0614098601$

: Komputerisasi Akuntansi

: Fakultas Ilmu Terapan

: Universitas Sains dan Teknologi

Semarang, Nopember 2021

Menyetujui

Kaprogdi D4-Komputerisasi Akuntansi

Ketua Penerbit YPAT

Iwan Kurniawan, S.E., M.Si.

Danang, S.Kom, M.Kom 


\section{PRAKATA}

Buku Sistem Informasi Manajemen Time Study dibuat sebagai bahan ajar dalam perkuliahan. Buku Sistem Informasi Manajemen Time Study dipakai sebagai acuan dosen yang mengajar mata kuliah Sistem Informasi Manajemen Time Study dan sebagai pedoman mahasiswa dalam memperdalam pemahaman mengenai mata kuliah Sistem Informasi Manajemen Time Study .

Pembahasan materi dalam buku Sistem Informasi Manajemen Time Study ini dimulai dari dasar pengenalan sistem informasi, manajemen, time study, perancangan sistem informasi dan desain sistem.

Harapannya buku ini dapat bermanfaat bagi dosen dan mahasiswa yang mengajar Sistem Informasi Manajemen Time Study. 


\section{KATA PENGANTAR}

Assalamualikum Wr.Wb

Puji Syukur ke Hadirat Allah SWT karena berkat rahmat dan hidayahnyalah Penulis dapat menyelesaikan pembuatan Buku ajar ini.

Pengaturan Time Study yang harus membuat form baru di Microsoft Excel akan menambah panjang waktu pengerjaan dan harus memahami logika excel. Belum adanya database serta sistem keamanan yang belum tersedia menjadi perimbangan dibutuhkannya sistem informasi pengelolaan anggaran pendapatan belanja desa yang akan membuat waktu lebih efektif dalam penyusunan anggaran. Sistem informasi ini menggunakan Visual Basic 6.0 dengan database MySql. Metode penelitian yang digunakan adalah R\&D yang dikembangkan oleh Borg and Gall (1983) yang melalui tahap sebagai berikut: Research and information collecting, Planning, Develop prelminary form of product, Prelminary field testing, Main product revision, Main field testing. Tujuan dari sistem informasi pengelolan manajemen time study diharapkan dapat membantu dalam pengaturan waktu sehingga waktu yang dibutuhkan dalam pembuatan laporan cukup efektif dan tidak terlambat, dalam penyusunan anggaran tidak perlu membuat form laporan karena form yang dibutuhkan telah tersedia. Dengan adanya pembagian hak akses dan sistem keamanan maka sistem informasi pengelolaan manajemen time study diharapkan akan lebih aman.

Sebelum mengakhiri kata pengantar ini, ijinkanlah penulis mengucapkan terima kasih pada pihak-pihak yang memungkinkan diterbitkannya buku ini, yaitu semua staff di STEKOM Semarang. Untuk teman teman tercinta, terima kasih atas dorongan serta cintamu. Tak ada yang lebih indah di dunia ini selain saling mencintai serta saling berbagi.

Wassalamualaikum Wr.Wb

Penulis 


\section{Daftar Isi}

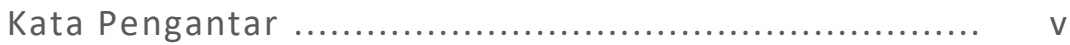

Bab 1 Pendahuluan........................................................ 1

Bab 2 Sistem Informasi ................................................ 8

Bab 3 Penentuan Standar Waktu Kerja......................... 14

A. Capaian Pembelajaran.................................... 14

B. Materi .......................................................... 14

C. Evaluasi ........................................................... 21

D. Referensi................................................... 22 
Bab 4

A. Capaian Pembelajaran.................................. 23

B. Materi ............................................................... 23

C. Evaluasi .......................................................... 29

D. Referensi.................................................... $\quad 30$

Bab 5 Metode Penelitian...................................................... 31
A. Capaian Pembelajaran
31
B. Materi
31
C. Evaluasi
35
D. Referensi.
35

Bab 6 Perancangan Sistem.............................................. 36
A. Capaian Pembelajaran................................... 36
B. Materi ........................................................ 36
C. Evaluasi .......................................................... 55
D. Referensi...................................................... 55

Bab $7 \quad$ Desain Interface ................................................. 57

A. Capaian Pembelajaran................................ 57

B. Materi ......................................................... 57

C. Evaluasi ................................................... 62

D. Referensi....................................................... 62 


\section{BAB 1 \\ PENDAHULUAN}

\section{A. Capaian Pembelajaran:}

1. Mampu memahami Latar belakang Permasalahan

2. Mampu memahami identifikasi masalah

3. Mampu mengetahui dan memahami Tujuan dan manfaat system yang dibangun.

\section{B. Materi}

Perkembangan teknologi khususnya di bidang teknologi komputer dan informatika telah berkembang dengan sangat pesat telah menyentuh seluruh aspek kehidupan. Teknologi informatika menjadi hal yang tak terhindarkan bagi masyarakat karena setiap hari seluruh peradaban yang dekat dengan teknologi akan setiap waktu berhubungan dengan teknologi informatika. Teknologi informatika merupakan bagian suatu sistem yang biasa disebut sistem informasi. Sistem informasi secara luas dimanfaatkan untuk kebutuhan secara spesifik. Perusahaan merupakan salah satu objek pengguna sistem informasi yang tak bisa lepas dari sistem informasi.

Sistem informasi adalah kumpulan dari sub-sub sistem yang saling terintegrasi dan berkolaborasi untuk menyelesaikan masalah tertentu dengan cara mengolah data dengan alat yang namanya komputer sehingga memiliki nilai tambah dan bermanfaat bagi pengguna (Taufiq, 2013) Penggunaan sistem informasi di perusahaan sangatlah luas, mulai dari pencatatan 
sederhana, pengolahan informasi bahkan untuk kegiatan yang lebih rumit seperti melakukan perhitungan untuk tujuan manajemen. Menurut (Follet, 2005) manajemen adalah suatu proses yang menekankan keterlibatan dan aktivitas yang saling terkait untuk mencapai sasaran yang telah ditetapkan. Manajemen di dalam perusahaan sangat penting dikarenakan skala aktivitas yang dilakukan sangatlah luas dan besar kapasitasnya. Untuk membantu perusahaan dalam melakukan manajemen, perlu dikembangkan sistem informasi manajemen.

Menurut (Davis, 1991) sistem informasi manajemen adalah sebuah sistem manusia atau mesin yang terpadu (integrated) untuk menyajikan informasi guna mendukung fungsi operasi, menejemen, dan pengambilan keputusan dalam sebuah organisasi. Organisasi yang dimaksud adalah perusahaan yang terdiri dari kumpulan departemen yang saling terintegrasi satu sama lain. Sistem informasi manajemen dapat digunakan untuk malakukan pengolahan informasi guna mendapatkan informasi yang dapat membantu pihak manajemen dalam menentukan keputusan atau mengambil kebijakan manajemen seperti halnya pada PT. Eka Sandang Duta Prima.

PT Eka Sandang Duta Prima adalah perusahaan yang bergerak dibidang manufaktur. Produk yang dihasilkan adalah sweater. Jenis sweater yang dihasilkan antara lain: sweater crew neck, v neck, turle neck, cardigan, hoodie, scraf, dan hat. Produk 
itu diproduksi apabila ada pesanan dari cutomer. Bahan baku yang digunakan adalah benang. Dalam memenuhi permintaan customer, perusahaan akan membuat contoh sweater terlebih dahulu kemudian di kirim ke customer untuk mendapatkan persetujuan, setelah semua contoh sweater sesuai dengan spesifikasi termasuk harga dan leadtimenya (waktu pengerjaan dari mulai pesan sampai barang dikirim ke customer), perusahaan akan mulai memproduksi. Dalam penentuan jumlah pekerja, biaya dan waktu pengerjaan sangat dibutuhkan standar waktu pengerjaan satu unit sweater. Penentuan standar waktu kerja yang cepat dan akurat dapat memberikan jawaban mengenai harga dan waktu pengerjaan yang cepat kepada customer. Perusahaan produksi sangat mementingkan efisiensi waktu dikarenakan semakin efisien waktu produksi maka semakin banyak produk yang dapat dihasilkan dan semakin banyak pendapatan yang dapat dihasilkan. Dalam melakukan manajemen waktu produksi terdapat metode penentuan standar waktu kerja yaitu metode time study.

Metode penentuan standar waktu kerja di PT. Eka Sandang Duta Prima menggunakan metode time study. Pengukuran waktu kerja adalah metode penerapan keseimbangan antara kegiatan manusia yang dikontribusikan dengan unit output yang dihasilkan (Wignjosoebroto, 2012). Untuk menghitung waktu baku (standart time) penyelesaian pekerjaan guna memilih 
alternatif metode kerja terbaik, maka perlu diterapkan prinsipprinsip dan teknik-teknik pengukuran kerja (work measurement atau time study). Waktu baku ini merupakan waktu yang dibutuhkan oleh seorang pekerja yang memiliki tingkat kemampuan rata- rata untuk menyelesaikan suatu pekerjaan (Wignjosoebroto, 2012). Metode perhitungan waktu standar dapat diaplikasikan ke dalam sistem informasi berbasis web yang memiliki beberapa keunggulan diantaranya perhitungan yang dilakukan oleh sistem.

Pada penelitian yang dilakukan penulis, bagian Ironing dalam melakukan perhitungan standar waktu kerja terdapat beberapa kendala yang mengurangi kinerja bagian Ironing. Kendala tersebut yaitu pertama, proses pencatatan waktu kerja produksi yang belum terintegrasi antar tahapan dan bagian serta penginputan dan perhitungannya yang masih dihitung manual menjadikan proses kerja yang rumit dan tidak efisien. Kedua, belum adanya sistem informasi berbasis database untuk melayani pekerjaan secara terintegrasi antara tahapan dan antar bagian. Ketiga, pembuatan laporan yang masih dibuat satu persatu memakan waktu yang cukup lama dan membebani kinerja karyawan.

Berikut adalah tabel perhitungan waktu kerja standar yang dihitung manual pada PT. Eka Sandang Duta Prima: 


\begin{tabular}{|c|l|c|c|}
\hline \multirow{4}{*}{$\begin{array}{c}\text { Order } \\
\text { Style }\end{array}$} & Departemen & $\begin{array}{c}\text { Standar Waktu } \\
\text { Kerja (Menit) }\end{array}$ & $\begin{array}{c}\text { Produksi Unit } \\
\text { Per Jam (Pcs) }\end{array}$ \\
\hline AH8380 & Linking & 3.58 & 16.76 \\
\cline { 2 - 4 } & Linkcheck & 3.00 & 20.00 \\
\cline { 2 - 4 } & Stiching & 1.78 & 33.71 \\
\cline { 2 - 4 } & Ironing & 4.00 & 15.00 \\
\cline { 2 - 4 } & Sewing & 0.86 & 69.77 \\
\cline { 2 - 4 } & Inspect & 1.20 & 50.00 \\
\cline { 2 - 4 } & Mending & 1.15 & 52.17 \\
\cline { 2 - 4 } & Folding & 1.34 & 44.78 \\
\hline AN584 & Linking & 5.26 & 11.40 \\
\cline { 2 - 4 } & Linkcheck & 3.40 & 17.64 \\
\cline { 2 - 4 } & Stiching & 2.10 & 28.57 \\
\cline { 2 - 4 } & Ironing & 3.50 & 17.14 \\
\cline { 2 - 4 } & Sewing & 0.86 & 69.77 \\
\cline { 2 - 4 } & Inspect & 1.50 & 40.00 \\
\cline { 2 - 4 } & Mending & 1.00 & 60.00 \\
\cline { 2 - 4 } & Folding & 1.20 & 50.00 \\
\hline \multirow{5}{*}{ A0106 } & Linking & 4.25 & 14.11 \\
\cline { 2 - 4 } & Linkcheck & 2.40 & 25.00 \\
\hline
\end{tabular}

Dari tabel diatas menujukkan kebutuhan standar kerja waktu tiap departemen produksi. Setiap departemen dalam manajemen waktu belum memiliki standard waktu yang baku, maka perlu untuk membuat sistem informasi manajemen penentuan standar waktu kerja untuk mewujudkan sistem yang memiliki fungsi perhitungan yang dapat memudahkan karyawan dalam mengelola data. Selain itu, agar penentuan standar waktu kerja yang dapat diakses secara terintegrasi perlu dibuat suatu sistem informasi manajemen. Hal lain, sistem 
informasi manajemen diperlukan dalam efisiensi waku penyajian laporan per departemen.

Membangun sistem informasi manajemen ini untuk menentukan penentuan waktu kerja produksi, menghitung perkiraan waktu pengerjaan pesanan dan menginput data kontrol produksi. Bahasa pemrograman yang digunakan adalah Codeigniter 3, PHP, HTML dan Bootstrap sebagai template website. Jenis Database yang digunakan adalah MariaDB. Input yang terdapat dalam membangun sistem ini yaitu data order, data produk, data performance rating dan data waktu kerja. Setelah input dilanjutkan dengan proses perhitungan standard waktu kerja dan perencanaan waktu penyelesaian suatu order. Hasil proses ini memberikan output yaitu laporan data user, laporan standard waktu kerja dan planning production tiap order.

\section{Evaluasi}

1. Bagaimana membuat sistem yang dilengkapi dengan database untuk menentukan penentuan waktu kerja produsi ?

2. Bagaimana membuat sistem yang dilengkapi dengan sistem keamanan hak akses pengguna?

3. Bagaimana membuat sistem dengan jaringan komputer yang dapat memberikan laporan tiap produksi? 


\section{Referensi}

Davis, G. B. (1991). Kerangka dasar sistem informasi manajemen.

Follet, M. P. (2005). Pengertian Manajemen. Manajemen: Dasar, Pengertian Dan Masalah. PT Bumi Aksara, Jakarta.

Taufiq, R. (2013). Sistem Informasi Manajemen, Analisis dan Metode Pengembangan. Yogyakarta: Graha Ilmu.

Wignjosoebroto. (2012). Ergonomi, studi gerak dan waktu : teknik analisis untuk peningkatan produktivitas kerja. University of Sumatera Utara Library. 


\section{BAB 2 \\ SISTEM INFORMASI}

\section{A. Capaian Pembelajaran:}

1. Mampu memahami pengertian sistem

2. Mampu memahami pengertian informasi

3. Mampu mengetahui tujuan dan manfaat sistem informasi

B. Materi

\section{Pengertian Sistem}

Sistem adalah sekelompok elemen-elemen yang terintegrasi dengan tujuan yang sama untuk mencapai tujuan. Organisasi terdiri dari sejumlah sumber daya manusia, material, mesin, uang dan informasi. Sumber daya tersebut bekerja sama menuju tercapainya suatu tujuan tertentu yang ditemukan oleh pemillik atau manajemen (Yakub, 2012). Sistem adalah sekumpulan dari sub-sub sistem abstrak maupun fisik yang saling terintegrasi dan berkabolarisasi untuk mencapai suatu tujuan tertentu (Taufiq, 2013).

2. Pengertian informasi

Setiap harinya kita mampu memperoleh informasi dari berbagai media seperti informasi dari telepon, televisi, atau radio. Yang dimaksud dengan informasi dalam bahasan ini ialah proses lebih lanjut dari data yang sudah memiliki nilai tambah (Sutabri, 2012). Informasi merupakan hasil dari pengolahan data menjadi bentuk yang lebih berguna bagi yang menerimanya yang menggambarkan suatu kejadian-kejadian nyata dan dapat digunakan sebagai alat bantu untuk pengambilan suatu keputusan (Djahir, 2015). 


\section{Nilai Informasi}

Fungsi Informasi yang dibutuhkan untuk mengambil keputusan terkadang diperlukan dengan proses yang cepat dan tidak terduga. Hal itu mengakibatkan penggunaan informasi hanya berdasarkan perkiraan-perkiraan serta informasi yang apa adanya. Dengan perlakuan seperti ini mengakibatkan keputusan yang diambil tidak sesuai dengan yang diharapkan. Oleh karena itu untuk memperbaiki keputusan yang telah diambil maka pencarian informasi yang lebih tepat perlu dilakukan. Suatu informasi memiliki nilai karena informasi tersebut dapat menjadikan keputusan yang baik serta menguntungkan (memiliki nilai informasi yang tepat). Nilai dari informasi ditentukan oleh lima hal yaitu :

1) Untuk memperoleh pemahaman dan manfaat.

2) Untuk mendapatkan pengalaman.

3) Pembelajaran yang terakumulasi sehingga dapat diaplikasikan dalam pemecaham masalah.

4) Untuk mengekstrak inplikasi kritis dan merefleksikan pengalaman masa lampau lampau yang menyediakan pengetahuan yang terorganisasi dengan nilai yang tinggi. Nilai ini bisa menghindari seorang manajer dari membuat kesalahan yang sama yang dilakukan oleh manajer lain sebelumnya. 
4. Pengertian Sistem Informasi

Sisem informasi adalah kumpulan dari sub-sub sistem yang saling terintegrasi dan berkolaborasi untuk menyelesaikan masalah tertentu dengan cara mengolah data dengan alat yang namanya komputer sehingga memiliki nilai tambah dan bermanfaat bagi pengguna (Taufiq, 2013). Sistem Informasi adalah suatu sistem didalam suatu organisasi yang mempertemukan kebutuhan pengolah transaksi harian yang mendukung fungsi operasi organisasi yang bersifat manajerial dengan kegiatan strategi dari suatu organisasi untuk dapat menyediakan kepada pihak luar tertentu dengan laporanlaporan yang diperlukan (Sutabri, 2012).

5. Pengertian Manajemen

Manajemen merupakan suatu penggunaan atau pemanfaatan sumber daya untuk mencapai suatu tujuan, menurut Sutanta (2011:17). Umumnya sumber daya yang tersedia dalam manajemen meliputi manusia, materil, dan modal. Sedangkan menurut Hasibuan $(2016 ; 1)$ manajemen adalah ilmu dan seni mengatur proses pemanfaatan sumber daya manusia dan sumber-sumber lainnya secara efektif dan efisien untuk mencapai suatu tujuan tertentu.

Jadi manajemen adalah kegiatan yang dilakukan untuk menyelesaikan suatu pekerjaan atau aktifitas secara bersama-sama atau melibatkan orang lain demi mencapai suatu tujuan yang sama dengan memanfaatkan sumber daya yang ada. 


\section{Pengertian Data}

Hartono (2013:15), "Data adalah hasil pengukuran dan pencatatan terhadap fakta tentang sesuatu, keadaan, tindakan, atau kejadian." Asropudin (2013:22) menjelaskan, "Data adalah kumpulan dari angkaangka maupun karakter-karakter yang tidak memiliki arti." Sujatmiko (2012:76), Data adalah kumpulan dari angka-angka maupun karakter-karakter yang tidak memiliki arti. Data dapat diolah sehingga menghasilkan informasi.

Dari beberapa definisi di atas dapat disimpulkan bahwa data adalah sekumpulan fakta yang harus diolah lebih lanjut untuk menghasilkan suatu informasi.

\section{Pengertian Sistem Informasi Manajemen}

Menurut Davis (2010:3) sistem informasi manajemen adalah sebuah sistem manusia atau mesin yang terpadu (integrated) untuk menyajikan informasi guna mendukung fungsi operasi, menejemen, dan pengambilan keputusan dalam sebuah organisasi. Sedangkan menurut Moekijat (2009:17) berpendapat bahwa sistem informasi manajemen adalah jaringan prosedur pengolah data oleh suatu organisasi dan disatukan apabila dipandang perlu dengan maksud memberikan data yang bersifat intern maupun data yang bersifat ekstern untuk dasar pengambilan keputusan dalam rangka mencapai tujuan organisasi. Sistem informasi manajemen di dalam 
pelaksanaanya menggunakan beberapa komponen yaitu perangkat keras (hardware) dan perangkat lunak (software) komputer, berkas file atau sekumpulan data yang tersimpan baik, prosedur atau pedoman di dalam pengoperasian sistem informasi, manusia atau (brainware) atau manusia yang terlibat di dalam pengoperasian sistem informasi.

\section{Evaluasi}

1. Jelaskan tentang sistem !

2. Apa perbedaan informasi dan data!

3. Apa syarat informasi ?

4. Apa tujuan manajemen?

5. Apa manfaat SIM bagi manajemen?

\section{Referensi}

Asropudin, 2013; “ Sistem Basis Data”, Salemba 4

Davis, Gordon B, 2010;"Kerangka Dasar : Sistem Informasi Manajemen", Jakarta: PT. Pustaka Binawan Pressindo.

Djahir, Y dan Pratita, D 2015; "Bahan Ajar Sistem Informasi Manajemen”, Yogyakarta : Budi Utama.

Hartono, 2013; “ Metoda Pengumpulan dan Teknik Analisis Data”, Penerbit Andi

Hasibuan, Malayu S.P., 2016 ;'Manajemen Sumber Daya Manusia”, Edisi Revisi, Jakarta : PT Bumi Aksara.

Moekjijat, 2009;"'Manajemen Personalia dan Sumber Daya Manusia”, Jakarta:Mandar Maju.

Sujatmiko, 2012;"'Sistem Informasi Manajemen", Salemba 4 Sutabri, Tata. 2012. “Analisis Sistem Informasi”, Yogyakarta: Andi. 
Sutanta, Edhy, 2011:"Sistem Informasi Manajemen", Yogyakarta : Graha Ilmu.

Taufiq, 2013; "Sistem Informasi Manajemen Konsep Dasar, Analisis dan Metode Pengembangan", Yogyakarta : Graha Ilmu.

Yakub 2012; "Pengantar Sistem Informasi", Yogyakarta: Graha Ilmu. 


\section{A. Capaian Pembelajaran:}

1. Mampu memahami pengukuran waktu kerja

2. Mampu memahami indikator pengukuran waktu kerja

3. Mampu mengetahui perhitungan time study

\section{B. Materi}

1. Pengukuran Waktu Kerja

Pengukuran waktu kerja adalah metode penerapan keseimbangan antara kegiatan manusia yang dikontribusikan dengan unit output yang dihasilkan (Wignjosoebroto, 2006). Untuk menghitung waktu baku (standart time) penyelesaian pekerjaan guna memilih alternative metode kerja terbaik, maka perlu diterapkan prinsip-prinsip dan teknik-teknik pengukuran kerja (work measurement atau time study). Waktu baku ini merupakan waktu yang dibutuhkan oleh seorang pekerja yang memiliki tingkat kemampuan rata-rata untuk menyelesaikan suatu pekerjaan (Wignjosoebroto, 2006).

Dengan demikian maka waktu baku yang dihasilkan dalam aktifitas pengukuran kerja ini dapat digunakan sebagai alat untuk membuat rencana penjadwalan kerja yang menyatakan berapa lama kegiatan itu harus berlangsung dan berapa output yang dihasilkan serta berapa pula jumlah tenaga kerja untuk menyelesaikan pekerjaan tersebut. 


\section{Indikator Dalam Penentuan Waktu Kerja}

\section{1) Performance Rating}

Dengan melakukan rating ini diharapkan waktu kerja yang diukur bias "dinormalkan" kembali. Ketidak normalan dari waktu kerja ini diakibatkan oleh operator yang bekerja secara kurang wajar yaitu bekerja dalam tempo atau kecepatan yang tidak sebagaimana mestinya (Wignjosoebroto, 2006). Untuk menormalkan waktu kerja yang diperoleh dari hasil pengamatan, maka hal ini dilakukan dengan mengadakan penyesuaian yaitu dengan cara mengalikan waktu pengamatan rata-rata dengan faktor penyesuaian/rating "P". Harga dari rating faktor ini adalah sebagai berikut:

a) Apabila operator dirasakan bekerja terlalu cepat yaitu bekerja diatas batas kewajaran (normal) maka rating faktor ini akan lebih besar dari pada satu ( $\mathrm{p}>1$ atau $\mathrm{p}>100 \%$ ).

b) Apabila operator dirasakan bekerja terlalu cepat yaitu bekerja dibawah batas kewajaran (normal) maka rating faktor ini akan lebih kecil dari pada satu $(\mathrm{p}<1$ atau $\mathrm{p}<100 \%)$. 
c) Apabila operator dirasakan bekerja secara normal atau wajar maka rating faktor ini diambil sama dengan satu $(\mathrm{P}=1$ atau $\mathrm{P}=100 \%$ ).

2) Waktu Pengerjaan

Waktu pengerjaan yang dimaksud adalah waktu yang dibutuhkan seorang karyawan dalam mengerjakan 1 tugas secara spesifik. Dalam penelitian ini waktu yang dihitung adalah waktu suatu departemen produksi dalam menyelesaikan suatu pekerjaan.

3. Perhitungan Time Study Pada PT. Eka Sandang Duta Prima

Berikut merupakan sampel perhitungan waktu kerja pada departemen ironing pada PT. Eka Sandang Duta Prima 2019:

Tabel 1. Sampel data perhitungan time study departemen ironing

\begin{tabular}{|r|r|r|}
\hline No & Performance Rating & Waktu (Menit) \\
\hline 1 & 0.90 & 1.03 \\
\hline 2 & 1.00 & 0.39 \\
\hline 3 & 0.45 & 2.10 \\
\hline 4 & 0.80 & 1.22 \\
\hline 5 & 1.00 & 0.41 \\
\hline 6 & 0.85 & 1.19 \\
\hline
\end{tabular}




\begin{tabular}{|r|r|r|}
\hline No & Performance Rating & Waktu (Menit) \\
\hline \hline 7 & 0.80 & 1.28 \\
\hline 8 & 0.90 & 1.02 \\
\hline 9 & 0.70 & 1.44 \\
\hline 10 & 0.80 & 1.27 \\
\hline 11 & 1.00 & 0.42 \\
\hline 12 & 1.00 & 0.33 \\
\hline
\end{tabular}

Tabel di atas merupakan contoh sampel yang diambil dari perhitungan time study PT. Eka Sandang Duta Prima pada departemen ironing tahun 2019. Performance rating didapatkan dari hasil penilaian oleh $I E$ terhadap kinerja pegawai pada suatu departemen produksi. Untuk perolehan data waktu juga didapatkan dari kinerja pegawai terhadap lamanya waktu penyelesaian suatu pekerjaan untuk menyelesaikan satu tahapan produksi pada satu item. Untuk langkah pertama perlu dihitung waktu standar tiap data dengan rumus :

$$
W k=\left(\frac{P r}{60}\right) \times t
$$

Keterangan :

$$
\begin{aligned}
& \mathrm{Wk}=\text { Waktu kerja } \\
& \mathrm{t}=\text { waktu penyelesaian tugas } \\
& \mathrm{Pr}=\text { Performance rating }
\end{aligned}
$$


Sistem Informasi

Maka dapat dihasilkan sebagai berikut :

\begin{tabular}{|c|c|c|c|}
\hline No & Performance Rating & Waktu (menit) & Waktu kerja (menit) \\
\hline 1 & 0.90 & 1.03 & 0.95 \\
\hline 2 & 1.00 & 0.39 & 0.65 \\
\hline 3 & 0.45 & 2.10 & 0.98 \\
\hline 4 & 0.80 & 1.22 & 1.09 \\
\hline 5 & 1.00 & 0.41 & 0.68 \\
\hline 6 & 0.85 & 1.19 & 1.12 \\
\hline 7 & 0.80 & 1.28 & 1.17 \\
\hline 8 & 0.90 & 1.02 & 0.93 \\
\hline 9 & 0.70 & 1.44 & 1.21 \\
\hline 10 & 0.80 & 1.27 & 1.16 \\
\hline 11 & 1.00 & 0.42 & 0.70 \\
\hline 12 & 1.00 & 0.33 & 0.55 \\
\hline
\end{tabular}

Berikut adalah rumus untuk menghitung rata-rata waktu kerja :

$$
\bar{x}=\frac{\sum W k}{n}
$$

Keterangan :

$$
\begin{aligned}
& \bar{x}=\text { Rata-rata waktu kerja } \\
& \sum \mathrm{t}=\text { Jumlah waktu kerja } \\
& \sum \mathrm{n}=\text { Jumlah data }
\end{aligned}
$$

Mencari rata-rata waktu kerja dari sampel data time study menggunakan rumus di atas adalah sebagai berikut :

$$
\begin{aligned}
& \bar{x}=\frac{\sum W k}{n} \\
& \bar{x}=\frac{11,19}{12} \\
& \bar{x}=0,93
\end{aligned}
$$


Dari perhitungan di atas maka didapatkan :

\begin{tabular}{|r|r|r|r|}
\hline No & $\begin{array}{c}\text { Performance } \\
\text { Rating }\end{array}$ & $\begin{array}{r}\text { Waktu } \\
\text { penyelesaian }\end{array}$ & $\begin{array}{c}\text { Waktu Kerja } \\
\text { (min) }\end{array}$ \\
\hline 1 & 0.90 & 1.03 & 0.95 \\
\hline 2 & 1.00 & 0.39 & 0.65 \\
\hline 3 & 0.45 & 2.10 & 0.98 \\
\hline 4 & 0.80 & 1.22 & 1.09 \\
\hline 5 & 1.00 & 0.41 & 0.68 \\
\hline 6 & 0.85 & 1.19 & 1.12 \\
\hline 7 & 0.80 & 1.28 & 1.17 \\
\hline 8 & 0.90 & 1.02 & 0.93 \\
\hline 9 & 0.70 & 1.44 & 1.21 \\
\hline 10 & 0.80 & 1.27 & 1.16 \\
\hline 11 & 1.00 & 0.42 & 0.70 \\
\hline 12 & 1.00 & 0.33 & 0.55 \\
\hline \multicolumn{3}{|c|}{ Jumlah Data } \\
\hline \multicolumn{2}{|c|}{ Jumlah Waktu Kerja } & 11.19 \\
\hline Rata-rata Waktu Kerja & & 0.93 \\
\hline
\end{tabular}

Untuk mengetahui waktu standar, maka rata - rata waktu kerja di kalikan allowence. Allowence atau waktu kelonggaran adalah sejumlah waktu yang ditambahkan dalam waktu normal untuk memenuhi kebutuhan pribadi, waktu - waktu tunggu ynag tak dapat di hindari, dan kelelahan. PT Eka Sandang mengunakan standar allowence $107.40 \%$, maka sebagai berikut :

$$
W s=A l \times \bar{x}
$$


Sistem Informasi

Keterangan :

$$
\begin{aligned}
& \text { Ws }=\text { Waktu standar } \\
& \bar{x}=\text { Rata-rata waktu kerja } \\
& \mathrm{Al}=\text { Allowence }
\end{aligned}
$$

Mencari rata-rata waktu standar dari sampel data time study menggunakan rumus di atas adalah sebagai berikut :

$$
\begin{aligned}
& W s=A l \times \bar{x} \\
& W s=107,4 \% \times 0,93 \\
& W s=1.00
\end{aligned}
$$

\begin{tabular}{|r|r|r|r|}
\hline No & $\begin{array}{c}\text { Performance } \\
\text { Rating }\end{array}$ & $\begin{array}{c}\text { Waktu } \\
\text { penyelesaian }\end{array}$ & $\begin{array}{c}\text { Waktu Kerja } \\
\text { (min) }\end{array}$ \\
\hline 1 & 0.90 & 1.03 & 0.95 \\
\hline 2 & 1.00 & 0.39 & 0.65 \\
\hline 3 & 0.45 & 2.10 & 0.98 \\
\hline 4 & 0.80 & 1.22 & 1.09 \\
\hline 5 & 1.00 & 0.41 & 0.68 \\
\hline 6 & 0.85 & 1.19 & 1.12 \\
\hline 7 & 0.80 & 1.28 & 1.17 \\
\hline 8 & 0.90 & 1.02 & 0.93 \\
\hline 9 & 0.70 & 1.44 & 1.21 \\
\hline 10 & 0.80 & 1.27 & 1.16 \\
\hline 11 & 1.00 & 0.42 & 0.70 \\
\hline 12 & 1.00 & 0.33 & 0.55 \\
Jumlah Data & & 12 \\
\hline Jumlah Waktu Kerja & & 0.93 \\
\hline Rata-rata Waktu Kerja & & 1.00 \\
\hline Allowence & & \\
\hline Waktu Standar & & \\
\hline
\end{tabular}




\section{Konsep Dasar Time Study}

Time Study adalah teknik pengukuran pekerjaan dengan cara pengumpulan data berdasarkan waktu yang dibutuhkan untuk menyelesaikan suatu pekerjaan. Metode Time Study digunakan untuk menghitung nilai standard time suatu pekerjaan (Pawiro, 2015).

Menurut Trisiany dan Halim (2006) kegunaan utama dari time study adalah menghasilkan waktu standar suatu pekerjaan dengan kondisi tertentu, sehingga setelah itu dapat dihitung produktivitasnya. Tahap-tahap dalam menentukan standard time yaitu :

1. Mengukur basic time, untuk mengetahui berapa lama waktu yang dibutuhkan untuk menyelesaikan suatu aktivitas pekerjaan.

2. Menentukan rate, untuk memberi bobot pekerjaan yang diteliti.

3. Menghitung standard time.

\section{Evaluasi}

1. Jelaskan tentang pengukuran waktu kerja !

2. Apa saja indikator dalam penentuan waktu kerja ?

3. Bagaimana perhitungan time study ?

4. Bagaimana rumus rata-rata waktu standar?

5. Jelaskan tahap-tahap dalam penentuan standar time study ! 


\section{E. Referensi}

Wignjosoebroto, Sritomo, 2006; " Pengantar Teknik dan Manajemen Industri “, Guna Widya, Surabaya.

Pawiro, 2015;" Metode Time Study", Salemba 4

Trisiany dan Halim, 2006;" Analisa Produktivitas Pekerja Denganmetode Time Study", Penerbit Andy 

A. Capaian Pembelajaran:
1. Mampu memahami sejarah UML
2. Mampu memahami diagram UML
3. Mampu memahami Use Case Diagram, Activity Diagram, Class Diagram

\section{B. Materi}

1. Sejarah UML

Bahasa pemrograman berorientasi objek yang pertama dikembangkan dikenal dengan nama Simula-67 yang dikembangkan pada tahun 1967. Perkembangan aktif dari pemrograman berorientasi objek mulai menggeliat ketika berkembangnya bahasa pemrograman Smalltalk pada awal 1980-an yang kemudian diikuti dengan perkembangan bahasa pemrograman berorientasi objek yang lainnya Sekitar lima tahun setelah Smalltalk berkembang, maka berkembang pula metode pengembangan berorientasi objek. Karena banyaknya metodologi - metodologi yang berkembang pesat saat itu, maka muncul lah ide untuk membuat sebuah bahasa yang dapat dimengerti semua orang. Maka dibuat bahasa yang merupakan gabungan dari beberapa konsep, seperti konsep Object Modeling Technique (OMT) dari Rumbaugh dan Booch (1991), konsep The Classes, Responsibilities, Collaborators (CRC) dari Rebecca WirfsBrock (1990), konsep pemikiran Ivar Jacobson, dan beberapa konsep 
lainnya dimana James R. Rumbaigh, Grady Booch, dan Ivar Jacobson bergabung dalam sebuah perusahaan yang bernama Rational Software Corporation menghasilkan bahasa yang disebut dengan Unified Modeling Language (UML).

\section{Diagram UML}

Shalahudin (2014:140), pada UML terdiri dari 13 macam diagram yang dikelompokkan dalam 3 kategori. Berikut ini penjelasan singkat dari pembagian kategori tersebut :

a. Structure diagram, yaitu kumpulan diagram yang digunakan untuk menggambarkan suatu struktur statis dari sistem yang dimodelkan. Structure diagram terdiri dari class diagram, object diagram, component diagram, composite structure diagram, package diagram dan deployment diagram.

b. Behavior diagram yaitu kumpulan diagram yang digunakan untuk menggambarkan kelakuan sistem atau rangkaian perubahan yang terjadi pada sebuah sistem. Behavior diagram terdiri dari Use case diagram, Activity diagram, State Machine System.

c. Interaction diagram yaitu kumpulan diagram yang digunakan untuk menggambarkan interaksi sistem dengan sistem lain maupun interaksi antar subsistem pada suatu sistem. Interaction diagram terdiri dari Sequence diagram, 
Communication diagram, Timing diagram, Interaction Overview Diagram.

\section{Use Case Diagram}

Menurut Shalahudin (2014:155), use case atau diagram use case merupakan pemodelan untuk kelakuan (behavior) sistem informasi yang akan dibuat. Use case mendeskripsikan sebuah interaksi antara satu atau lebih aktor dengan sistem informasi yang akan dibuat. Secara kasar, use case digunakan untuk mengetahui fungsi apa saja yang ada di dalam sebuah sistem informasi dan siapa saja yang berhak menggunakan fungsi-fungsi itu. Berikut adalah simbol-simbol yang ada pada diagram use case :

\section{Activity Diagram}

Menurut Shalahudin (2014:161), diagram aktivitas atau activity diagram menggambarkan workflow (aliran kerja) atau aktivitas dari sebuah sebuah sistem atau proses bisnis atau menu yang ada pada perangkat lunak. Yang perlu di perhatikan disini adalah bahwa diagram aktivitas menggambarkan aktivitas sistem bukan apa yang dilakukan aktor, jadi aktivitas yang dapat dilakukan oleh sistem. Berikut adalah simbol-simbol yang ada pada diagram aktivitas : 
Tabel 2.3 Simbol-simbol diagram use case.

\begin{tabular}{|c|l|c|}
\hline $\begin{array}{c}\text { Nama } \\
\text { Komponen }\end{array}$ & \multicolumn{1}{|c|}{ Keterangan } & Simbol \\
\hline Use Case & $\begin{array}{l}\text { Use case digambarkan sebagai lingkaran } \\
\text { elips dengan nama use case } \\
\text { dituliskan di dalam elips tersebut }\end{array}$ & Use case \\
\hline Actor & $\begin{array}{l}\text { Actor adalah pengguna sistem. Actor tidak } \\
\text { terbatas hanya manusia saja, melainkan } \\
\text { yang membutuhkan input atau } \\
\text { memberikan output, juga dianggap } \\
\text { sebagai actor. }\end{array}$ & $\begin{array}{l}\text { Asosiasi digunakan untuk } \\
\text { menghubungkan actor dengan use case. } \\
\text { Asosiasi digambarkan dengan sebuah } \\
\text { garis yang menghubungkan antara actor } \\
\text { dengan use case. }\end{array}$ \\
\hline
\end{tabular}

Sumber : Shalahudin, 2014.

\section{Class Diagram}

Menurut Shalahudin (2014:141), diagram kelas atau class diagram menggambarkan struktur sistem dari segi pendefinisian kelaskelas yang akan dibuat untuk membangun sistem. Kelas memiliki apa yang disebut atribut dan method atau operasi. Berikut penjelasan atribut dan method:

a. Atribut merupakan variable-variabel yang dimiliki oleh suatu kelas.

b. Operasi atau method adalah fungsi-fungsi yang dimiliki oleh suatu kelas. Berikut adalah simbol-simbol yang ada pada diagram kelas: 
Tabel 2.5 Simbol-simbol diagram class.

\begin{tabular}{|c|c|}
\hline Simbol & Keterangan \\
\hline Cass 2 & $\begin{array}{l}\text { Class : Deskripsi dari objek yang terbagi atas } 3 \text { bagian, } \\
\text { yaitu nama class pada bagian atas, atribut pada bagian } \\
\text { tengah dan operasi pada bagian bawah. }\end{array}$ \\
\hline & $\begin{array}{l}\text { Aggregation : Bentuk spesial dari hubungan asosiasi } \\
\text { yang memiliki hubungan secara spesifik antar kumpulan } \\
\text { dan sebuah bagian. Agregasi digambarkan dengan wajik } \\
\text { tidak berisi. }\end{array}$ \\
\hline & $\begin{array}{l}\text { Association : Menggambarkan hubungan terstruktur } \\
\text { antar class yang saling berelasi. }\end{array}$ \\
\hline & $\begin{array}{l}\text { Generalization : Relasi yang memperlihatkan suatu } \\
\text { kelas dapat lebih general atau lebih spesifik dari kelas } \\
\text { lainnya. }\end{array}$ \\
\hline
\end{tabular}

Sumber : Shalahudin, 2014.

\section{Sequence Diagram}

Menurut Shalahudin (2014:165), diagram sekuen menggambarkan kelakuan objek pada use case dengan mendeskripsikan waktu hidup objek dengan pesan yang dikirimkan dan diterima antar objek. Oleh karena itu untuk menggambarkan diagram sekuen maka harus diketahui objek-objek yang terlibat dalam sebuah use case beserta metode-metode yang dimiliki kelas yang diinstansiasi menjadi objek itu. 
Membuat diagram sekuen juga dibutuhkan untuk melihat skenario yang ada pada use case. Banyaknya diagram sekuen yang harus digambar adalah minimal sebanyak pendefinisian use case yang memiliki proses sendiri atau yang penting semua use case yang telah didefinisikan interaksi jalannya pesan sudah dicakup dalam diagram sekuen sehingga semakin banyak use case yang didefinisikan maka diagram sekuen yang harus dibuat juga semakin banayak. Berikut adalah simbol-simbol yang ada pada diagram sequence:

Tabel 2.6 Simbol-simbol diagram sequence.

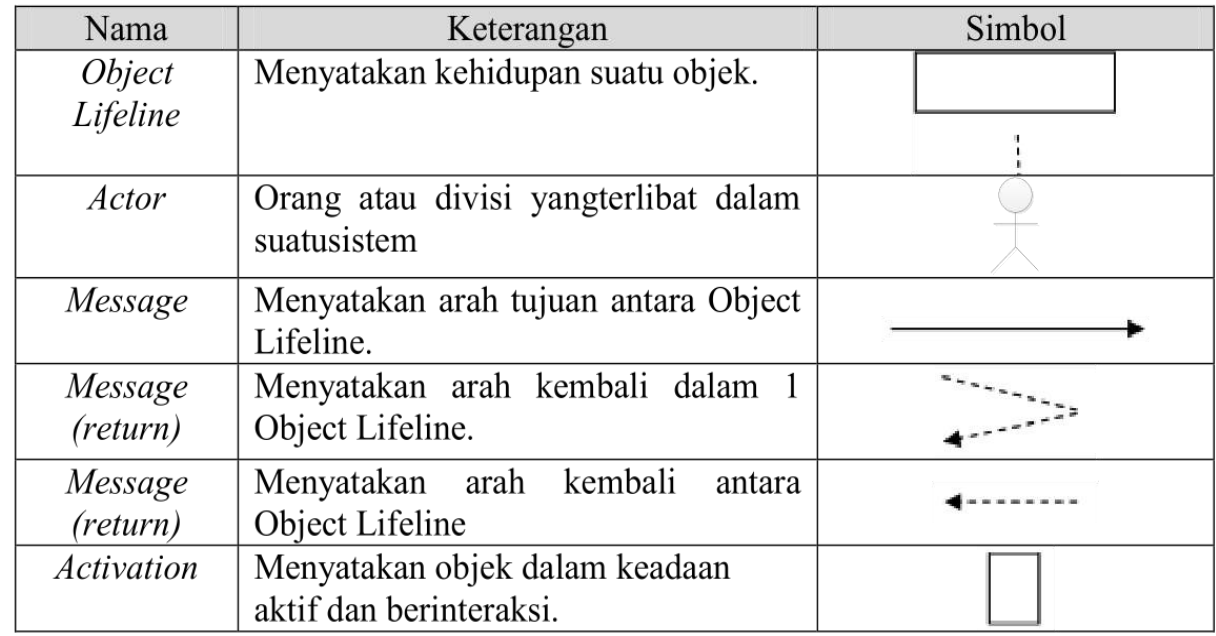

Sumber : Shalahudin, 2014. 


\section{Evaluasi}

1. Apa yang dimaksud UML ?

2. Apa manfaat UML ?

3. Jelaskan fungsi Use Case Diagram!

4. Jelaskan symbol-simbol dalam use case diagram !

5. Apa manfaat Class Diagram ?

D. Referensi

Shalahuddin, M dan Rosa A.S, 2014;" Rekayasa Perangkat Lunak Struktur dan Berorientasi Objek", Bandung : Informatika. 


\section{METODE PENELITIAN}

\section{A. Capaian Pembelajaran:}

1. Mampu memahami model pengembangan sistem

2. Mampu memahami prosedur pengembangan sistem

3. Mampu memahami R \& D

\section{B. Materi}

\section{Model Pengembangan}

Model pengembangan pada penelitian ini menggunakan pendekatan R\&D. Metode ini merupakan perbaikan metode yang dikembangkan dari Dick dan Carrey (Gall, 2003). Research And Development adalah rangkaian siklus riset dan pengembangan yang terdiri dari kajian temuan riset yang terkait dengan penelitian yang dikembangkan, pengembangan produk berdasarkan temuan-temuan riset, pengujian lapangan sesuai latar tempat produk yang akan digunakan, dan revisi produk untuk memperbaiki kekurangan dan kesalahan yang ditemukan di dalam setiap tahapan uji di lapangan. Siklus riset dan pengembangan dapat dilakukan beberapa kali pengulangan di tingkat lapangan sampai ditemukan bukti bahwa produk yang dikembangkan memenuhi kriteria untuk didesiminasikan. Dalam tahap pengembangan sistem informasi ini akan dibuat suatu bentuk rancangan. 


\section{Prosedur Pengembangan}

\section{- Langkah - Langkah R \& D}

Dalam penelitian ini penulis menggunakan prosedur pengembangan Research And Development, yaitu metode penelitian yang digunakan untuk menghasilkan produk, dan menguji keefektifan produk tersebut, beberapa tahapannya yaitu:

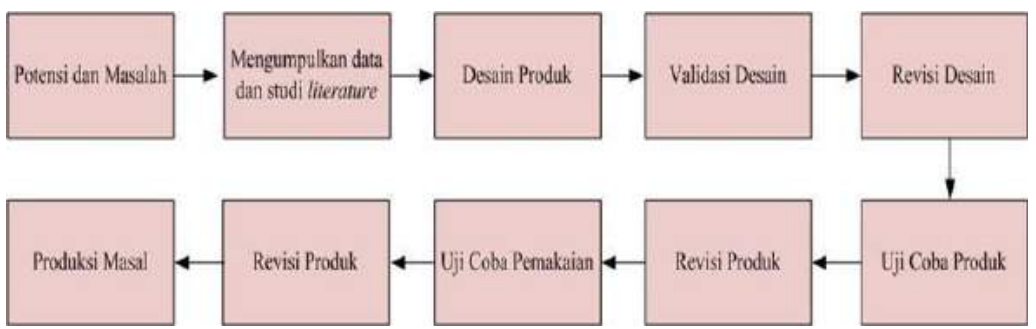

Gambar 3.5 Prosedur pengembangan metode R\&D. Sumber :

Sugiyono, 2015.

Langkah - langkah tersebut secara ringkas dijelaskan sebagai berikut:

A. Potensi dan masalah

Tahapan ini antara lain merumuskan permasalahan, menentukan tujuan, memperkirakan waktu penelitian dan Menentukan indikator yang dibutuhkan dalam pengelolaan laporan. Pada tahap ini penulis menidaklanjuti data permasalahan untuk mencari solusi yang layak diberikan yaitu sistem informasi penentuan standar waktu kerja metode time study.

B. Mengumpulkan informasi dan studi literature 
1. Melakukan wawancara pada bagian IE.

2. Observasi yang berkaitan dengan sistem akan dibuat yaitu perhitungan time study, data waktu kerja tiap divisi dan laporan perhitungan standar waktu kerja.

3. Penulis melakukan studi pustaka untuk mendapatkan teoriteori yang berkaitan dengan sistem yang akan dikembangkan melalui studi ke perpustakaan, buku-buku, jurnal dan media internet.

4. Penulis menyusun kerangka berfikir untuk memecahkan masalah yang diprogramkan berdasarkan teori R\&D.

C. Desain produk

Penulis membuat rancangan sistem informasi manajemen perhitungan standar waktu kerja yang nantinya akan digunakan oleh bagian IE. Perancangannya meliputi desain arsitektural berupa Use Case Diagram, Class Diagram, Sequence Diagram dan Activity Diagram. Bahasa pemrograman yang digunakan adalah HTML, PHP dan Codeigniter. Database yang digunakan adalah MariaDB.

D. Validasi desain

Melakukan uji validasi desain sistem informasi oleh pakar yang diwakili oleh dosen yang kompeten di bidang sistem informasi untuk mengetahui apakah desain yang dibuat sudah valid. Uji validasi desain dilakukan dengan menggunakan instrument 
penelitian berupa angket. Penilaian menggunakan angket terbagi atas 3 yaitu :angket pertama ditujukan kepada pengujia akademik. Angket kedua ditujukan kepada penguji eksternal dan angket ketiga ditujukan oleh calon pengguna.

E. Uji coba produk di lapangan oleh calon pengguna sistem

Setelah desain sistem dinyatakan valid oleh pakar, kemudian source code desain sistem dibuat menjadi prototype produk aplikasi. Produk aplikasi akan diuji di lapangan oleh calon pengguna yaitu untuk mengetahui apakah sistem sudah dibuat sesuai kebutuhan di lapangan. Hasil akhir akan dimasukkan ke dalam angket. Hasil angket harus dinyatakan baik oleh pengguna sistem.

F. Produksi masal

Setelah melewati tahap uji coba produk di lapangan oleh calon pengguna sistem, produk mendapat perbaikan sesuai saran dari caloh pengguna sistem dan pakar ahli. Setelah produk dinyatakan layak oleh calon pengguna sistem maupun pakar ahli akan diterapkan dan diproduksi masal sesuai tujuan.

\section{Evaluasi}

1. Jelaskan tentang model pengembangan sistem !

2. Jelaskan tahap-tahap dalam R \& D !

3. Apa yang dilakukan pada tahap studi literature ? 
Sistem Informasi

4. Jelaskan fungsi R \& D !

5. Jelaskan tahap pada Validasi !

D. Referensi

Gall, 2003

Sugiyono, 2015 


\section{A. Capaian Pembelajaran:}

1. Mampu memahami pengukuran waktu kerja

2. Mampu memahami kinerja sistem lama

3. Mampu merancang kinerja sistem baru

\section{B. Materi}

Objek penelitian yang digunakan peneliti untuk melakukan penelitian adalah di PT Eka Sandang Duta Prima yaitu sebuah perusahan yang beralamat di Jl. Syeh Basyarudin, Kaber Pt C 18 Kav.B Pringapus Jawa Tengah. PT Eka Sandang Duta Prima berdiri sejak tahun 2001.

\section{Narasi Sistem yang Berjalan Saat Ini}

1. Proses perhitungan waktu standar berawal dari IE Technician melakukan time study pada tiap tiap bagian produksi

2. kemudian mencatatnya dalam sebuah form dan

3. menginput manual pada excel yang kemudian

4. hasil waktu standar tersebut di laporkan kepada supervisior produksi dan pimpinan. 
Sistem Informasi

Flow of Document Sistem Lama

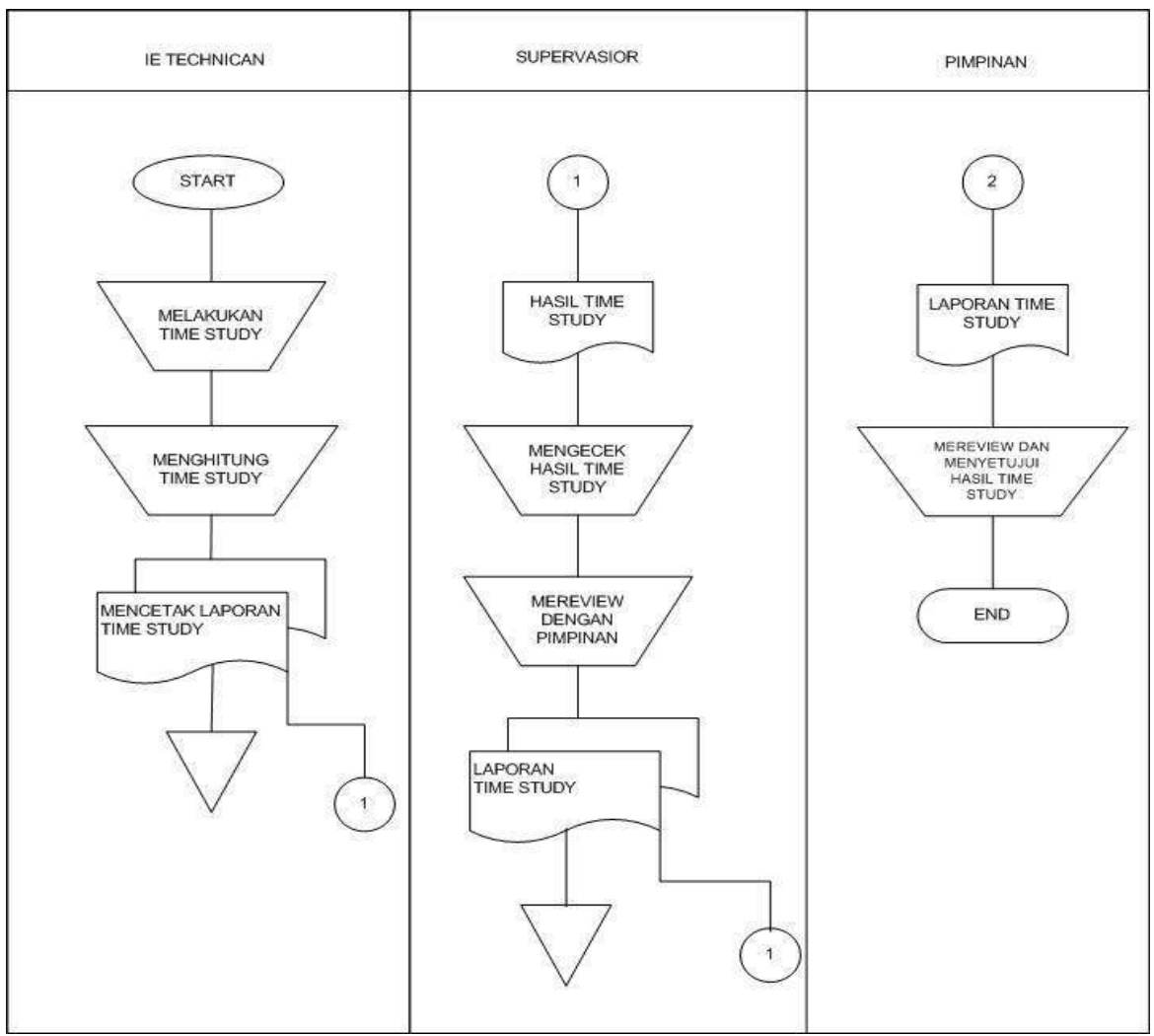

Narasi sistem yang dikembangkan

IE techinician melakukan timestudy dan menginput data timestudy.

1. IE technician menginput data time study kedalam database dan melakukan olah data pada web Sistem Informasi Manajemen Penentuan Standar Waktu Kerja.

2. Pimpinan dan Supervisor melihat dan mereview standar waktu 
Sistem Informasi

kerja.

Flow Document Sistem yang dikembangkan

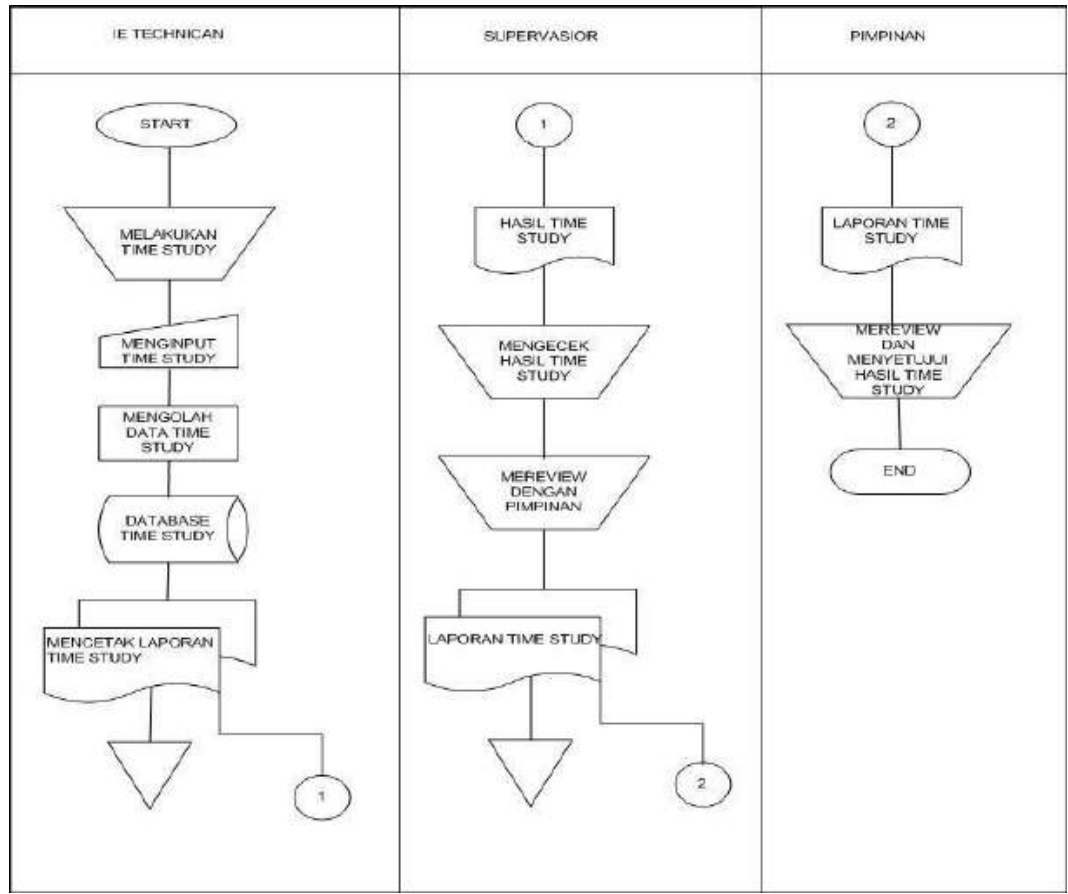


Desain Uji Coba Sistem yang dikembangkan

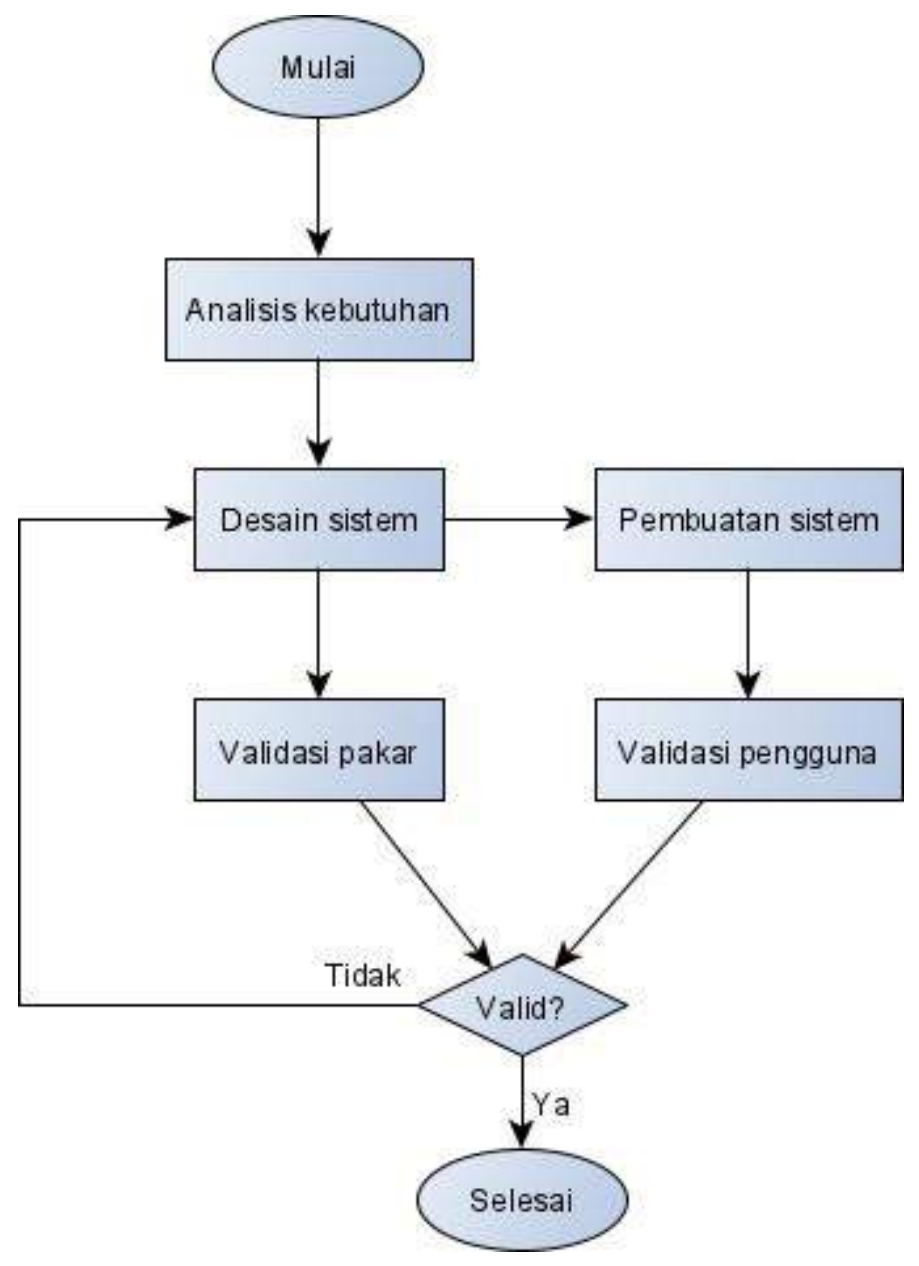




\section{Perancangan Sistem}

Diagram Usecase

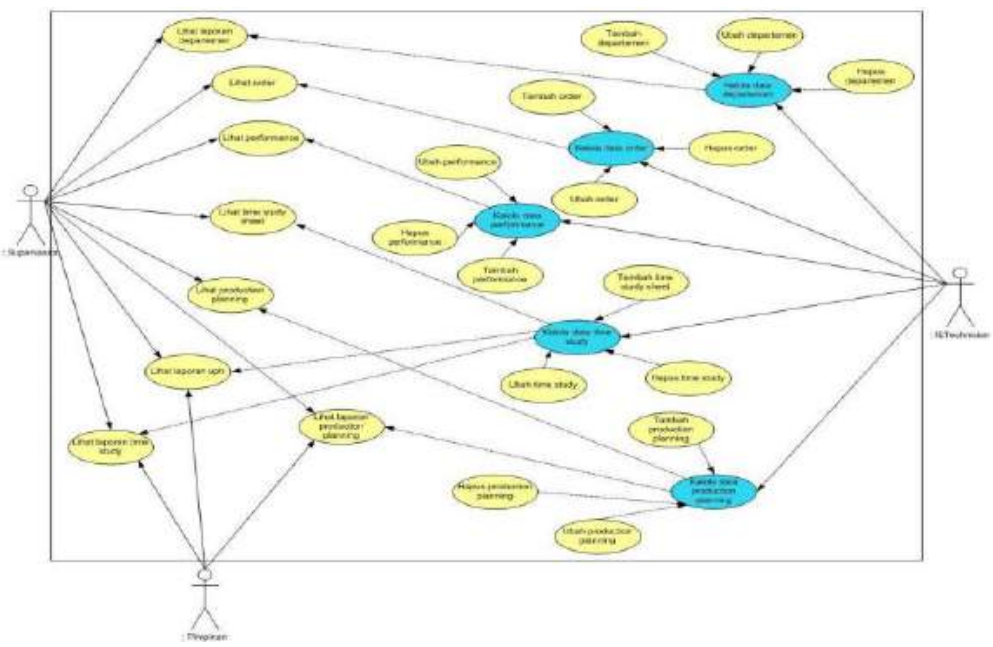

\section{Diagram Sequence}

Desain Diagram Sequence IE Kelola Data Departemen

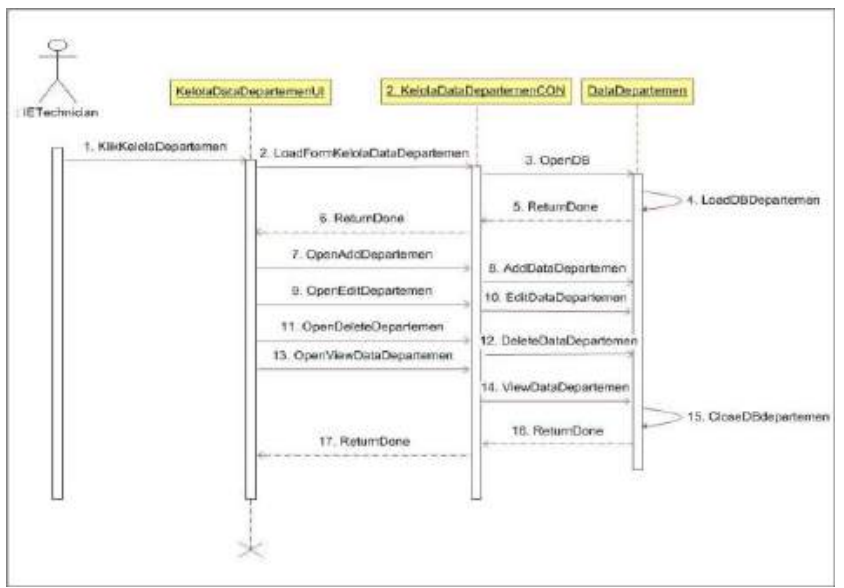

Desain Diagram Sequence IE Kelola Data Order 
Sistem Informasi

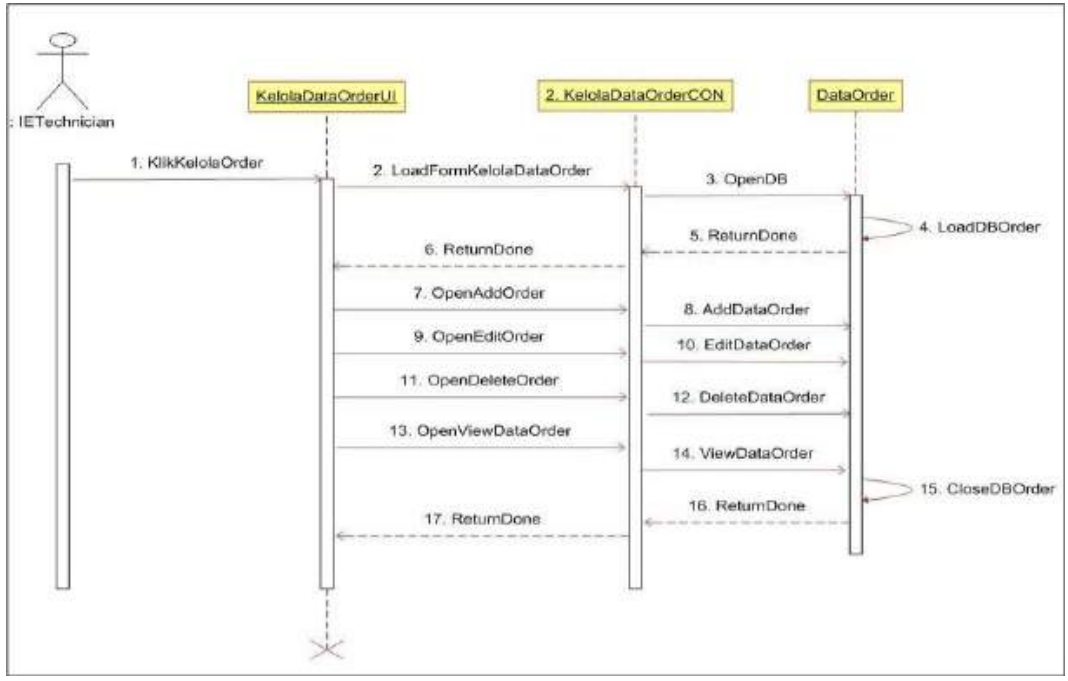

\section{Desain Diagram Sequence IE Kelola Data Performance}

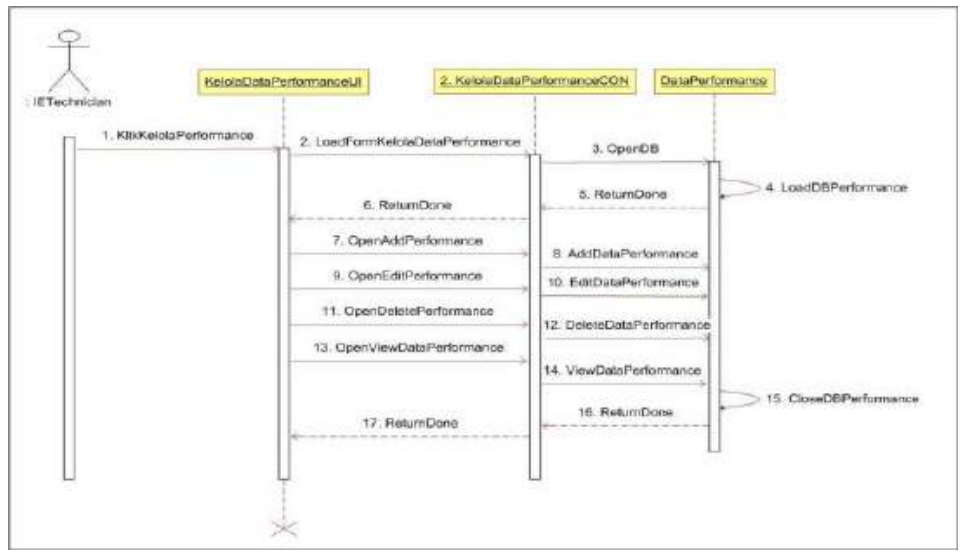




\section{Desain Diagram Sequence IE Kelola Data TimeStudy}

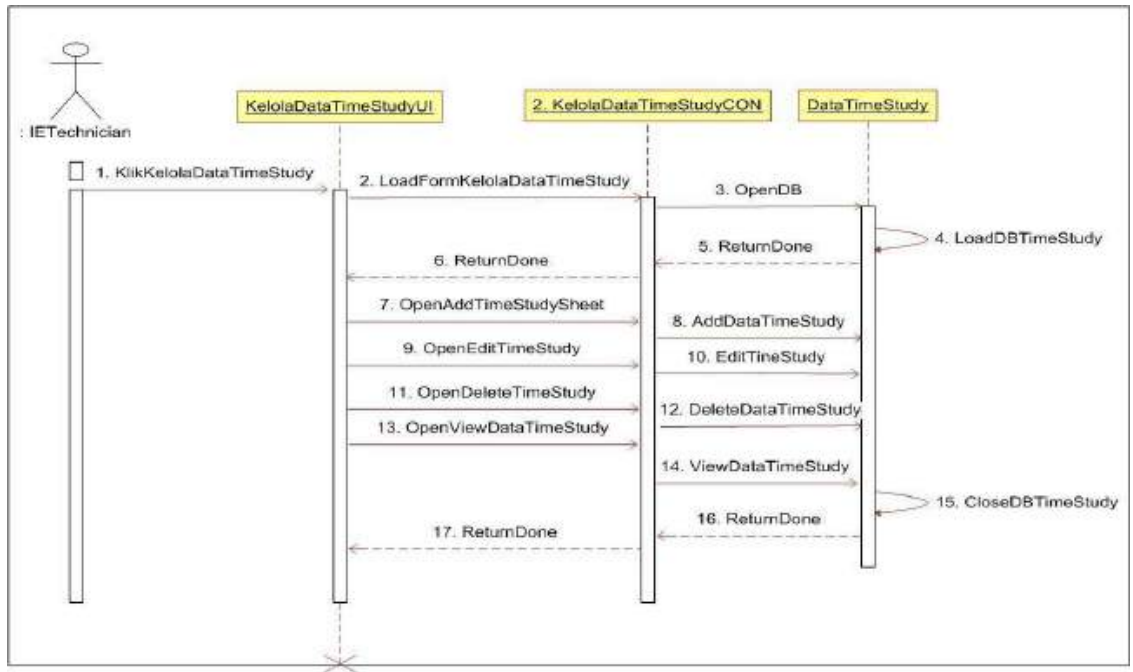

\section{Desain Diagram Sequence IE Kelola Data Production Planning}

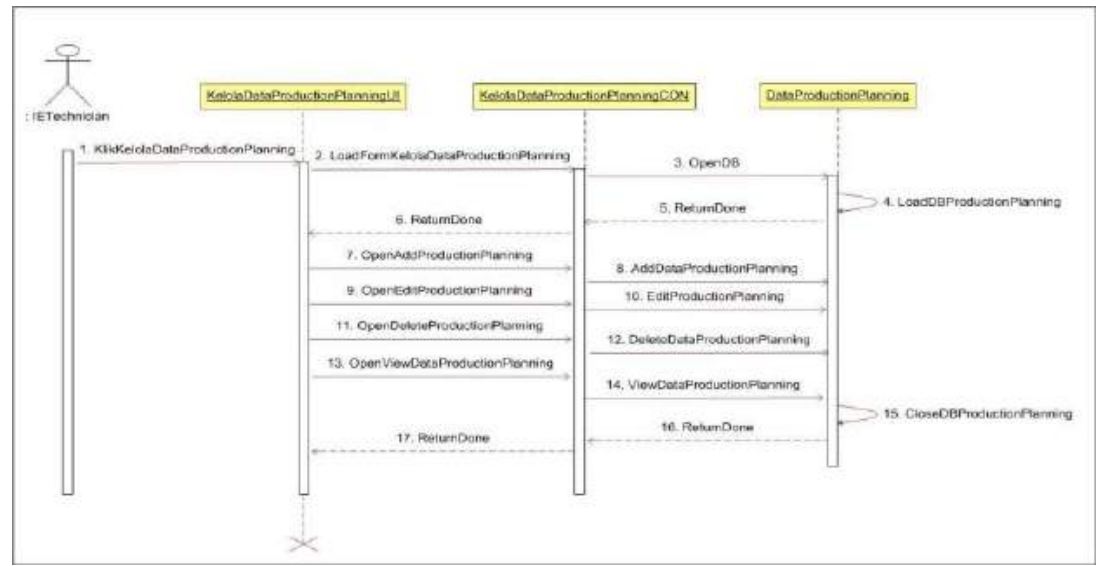

Desain Diagram Sequence Supervisior Laporan Departemen 
Sistem Informasi

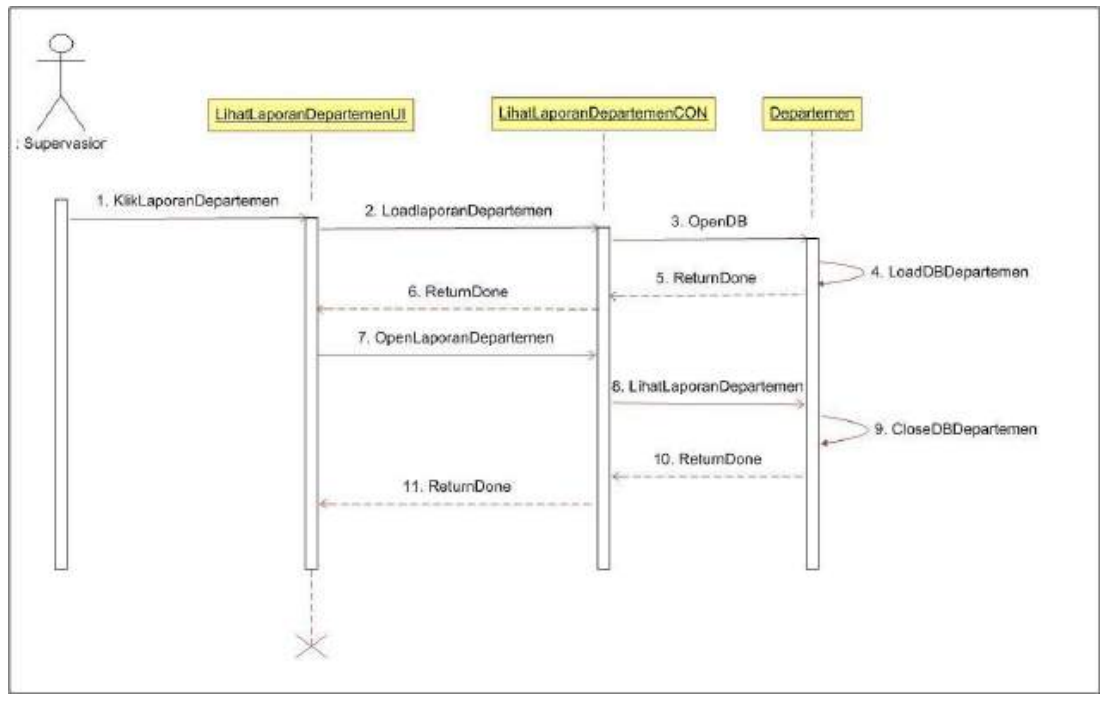

\section{Desain Diagram Sequence Supervisior Laporan Order}

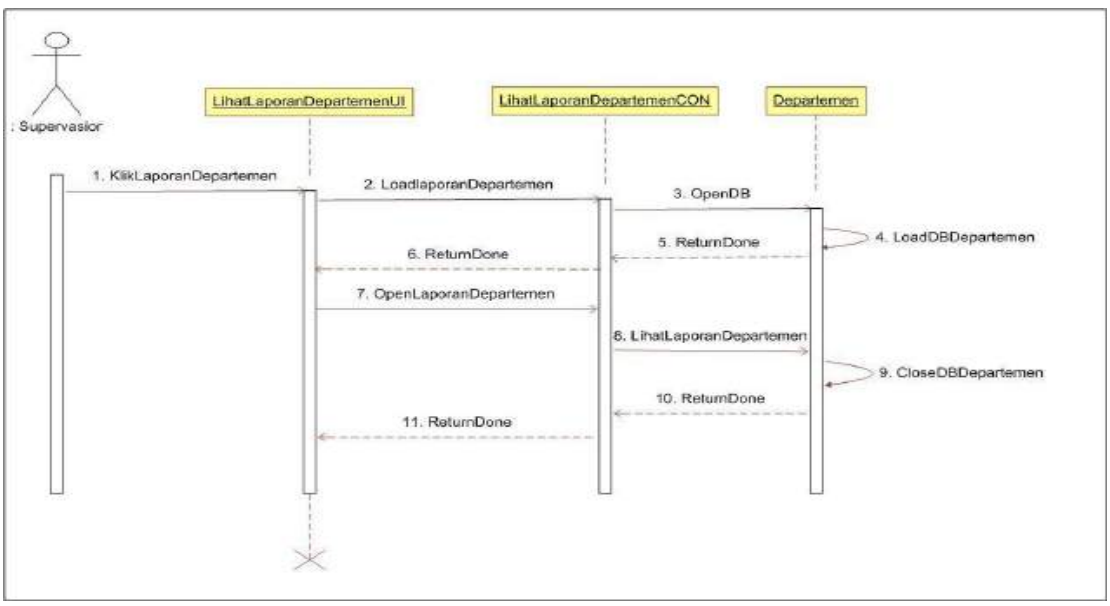


Desain Diagram Sequence Supervisior Laporan Performance

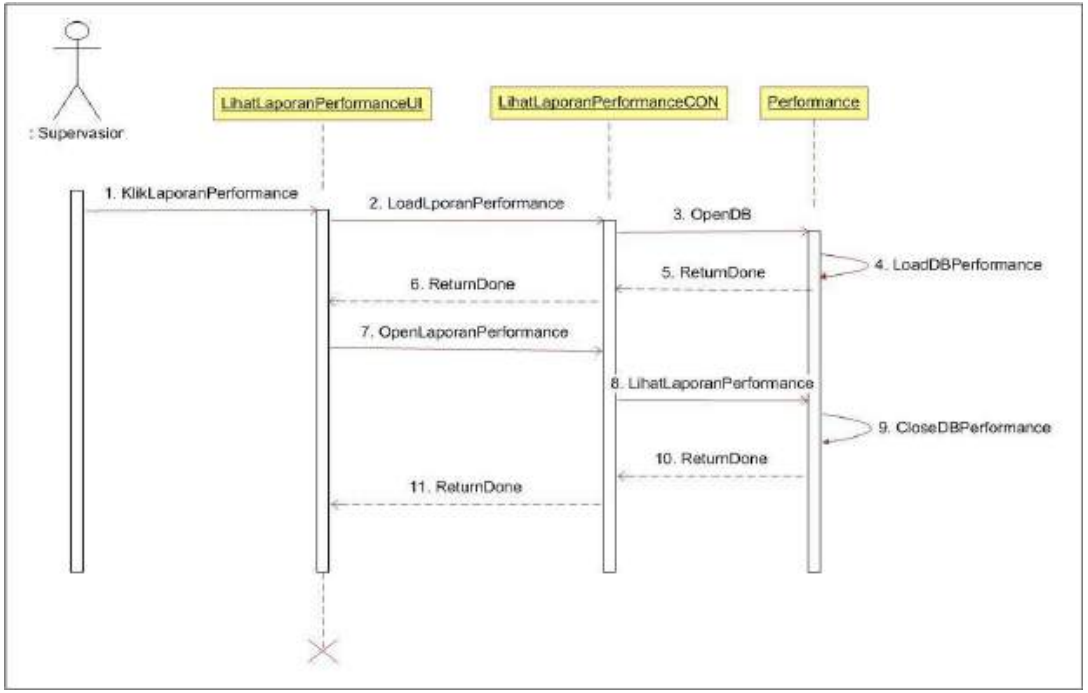

\section{Desain Diagram Sequence Supervisior Laporan TimeStudy}

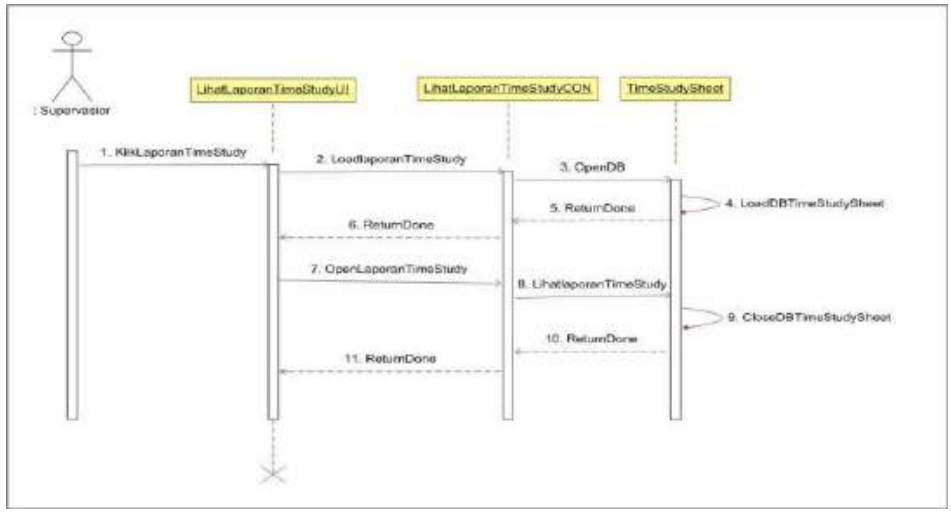


Desain Diagram Sequence Supervisior Laporan Production Planning

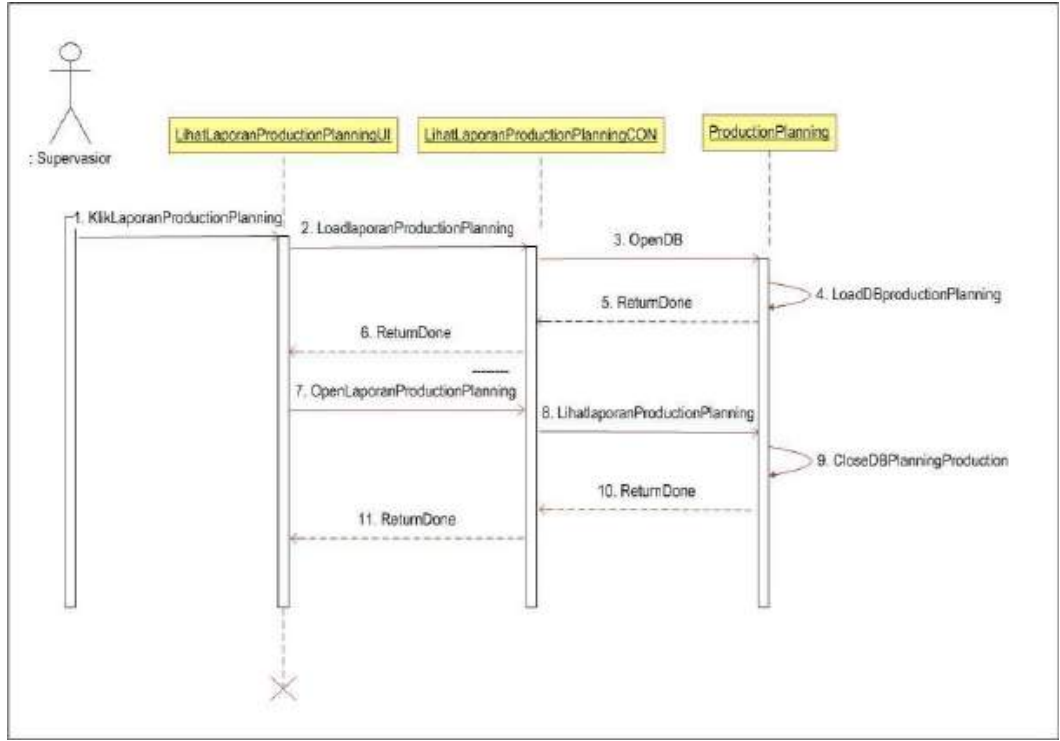

Desain Diagram Sequence Supervisior Laporan UPH

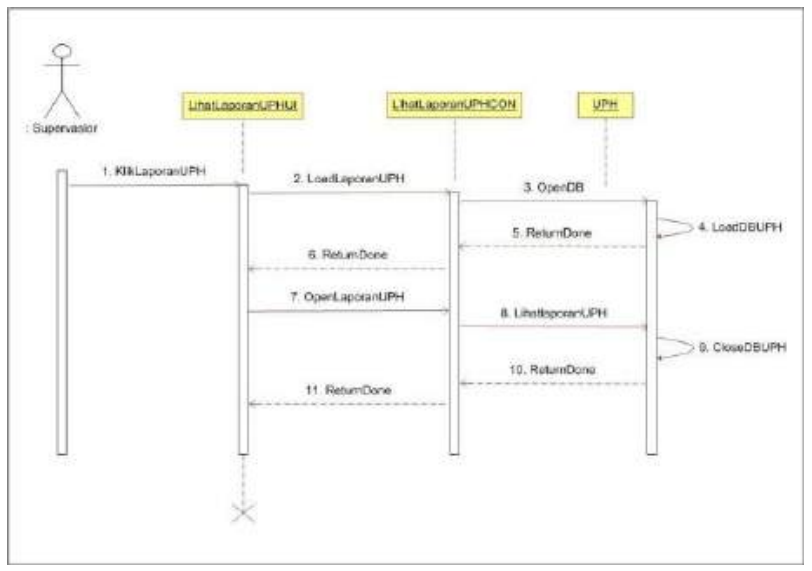

Desain Diagram Sequence Pimpinan Laporan TimeStudy 
Sistem Informasi

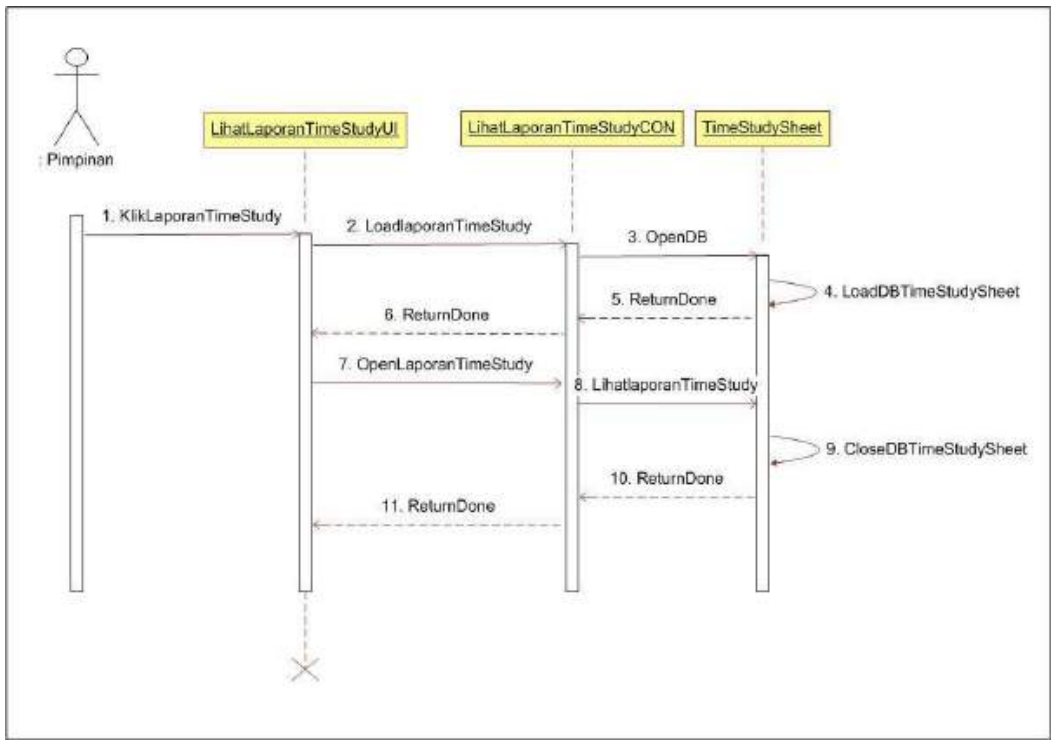

Desain Diagram Sequence Pimpinan Laporan Production Planning

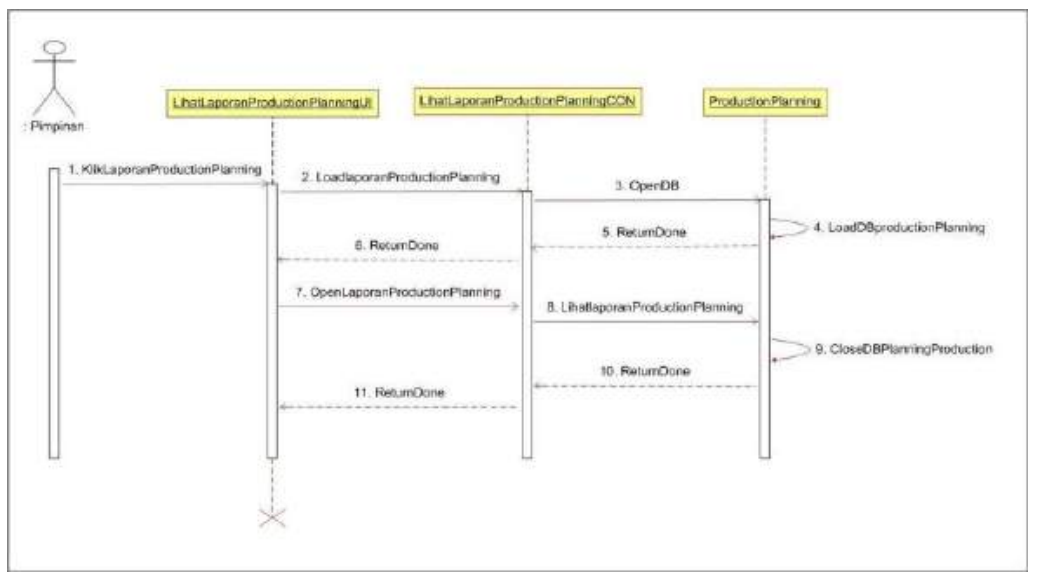

Desain Diagram Sequence Pimpinan Laporan UPH 
Sistem Informasi

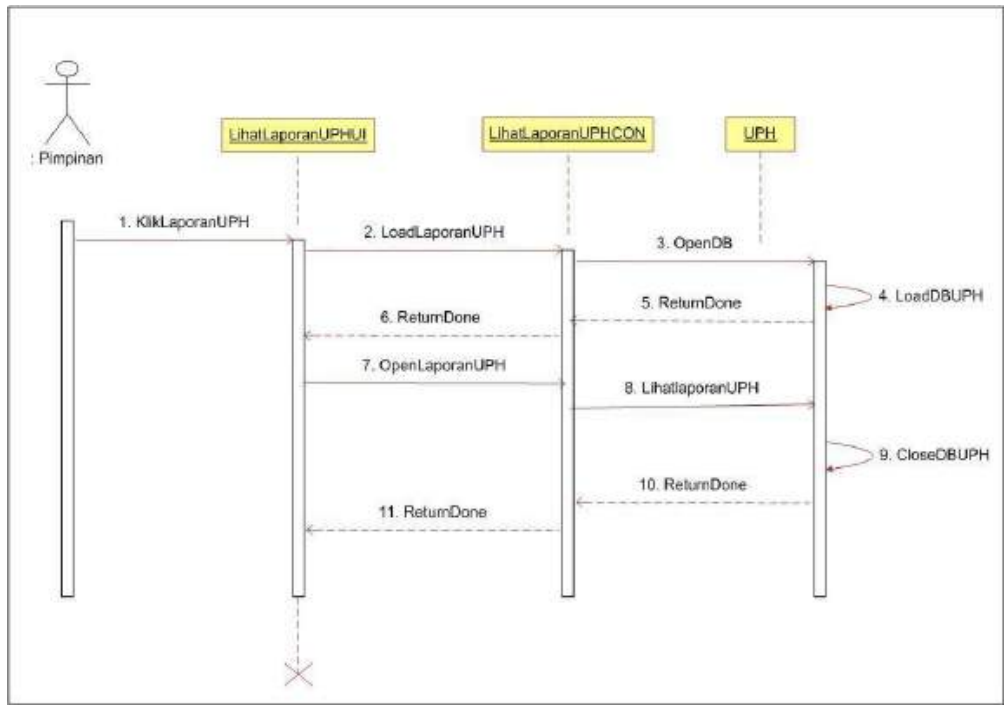

\section{Diagram Activity}

Desain Diagram Activity IE Kelola Data Departemen.

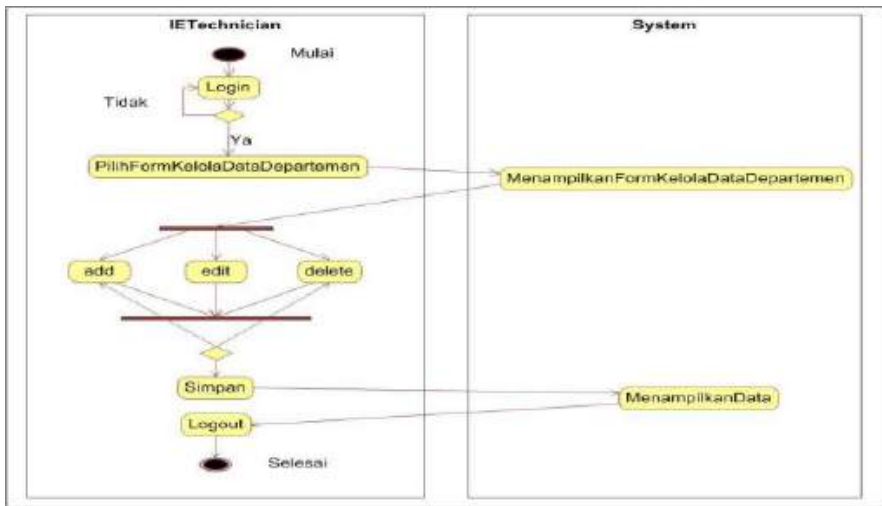

Desain Diagram Activity IE Kelola Data Order 
Sistem Informasi

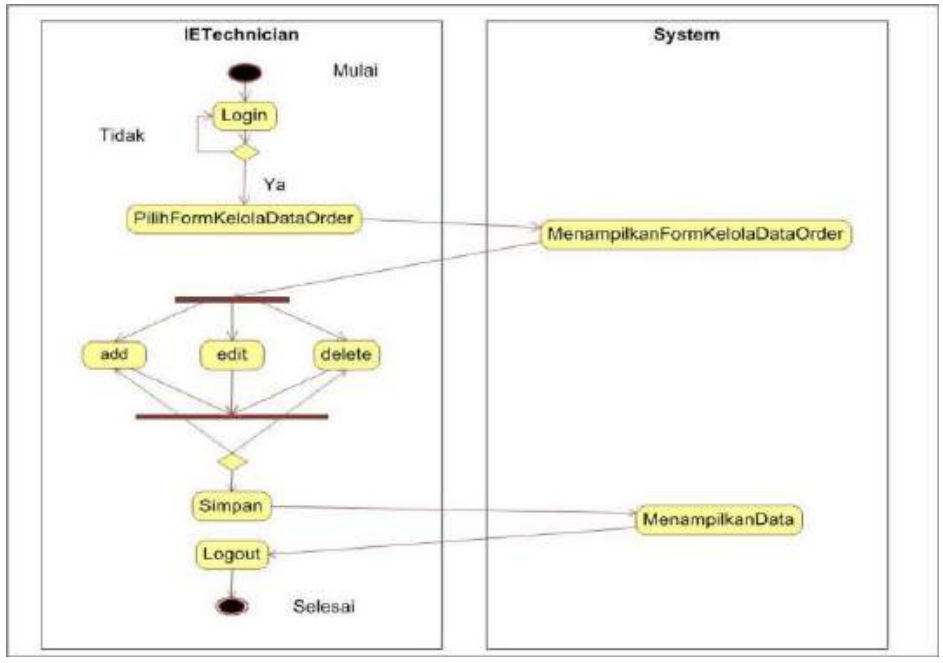

\section{Desain Diagram Activity IE Kelola Data Performance.}

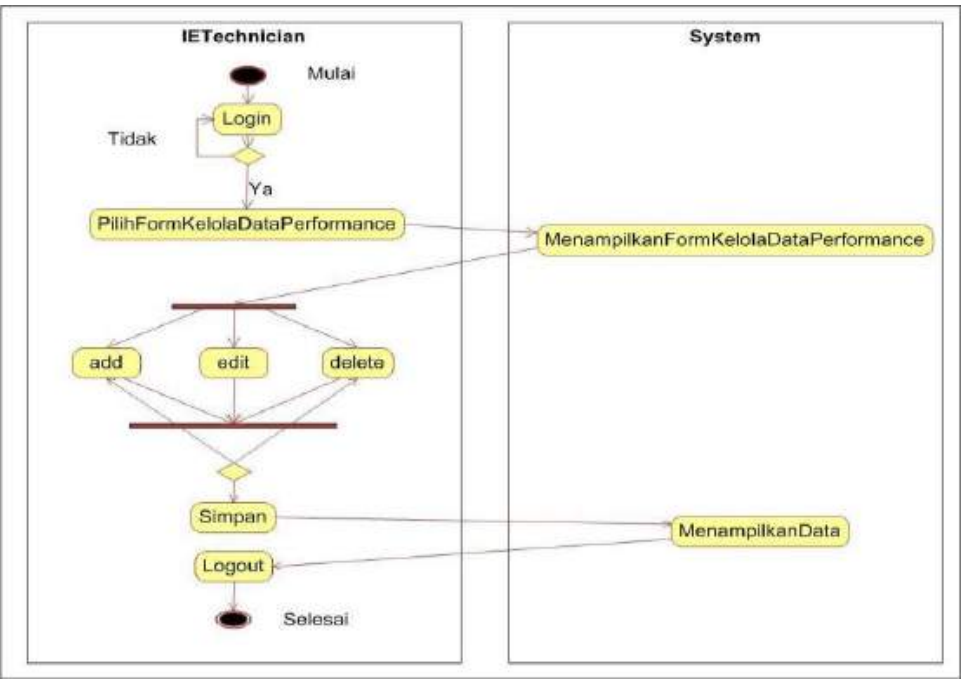

Desain Diagram Activity IE Kelola Data TimeStudy. 
Sistem Informasi

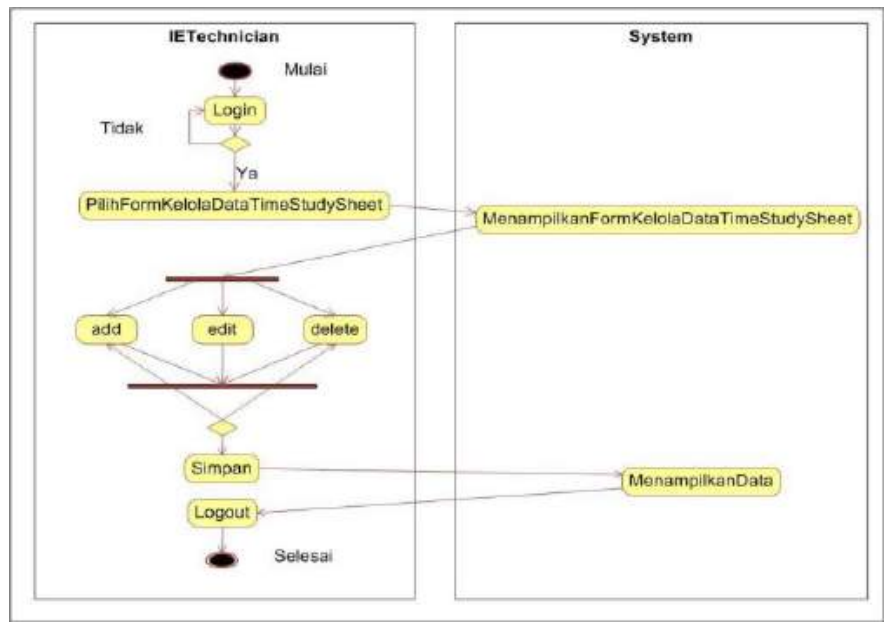

\section{Desain Diagram Activity IE Kelola Data Production Planning}

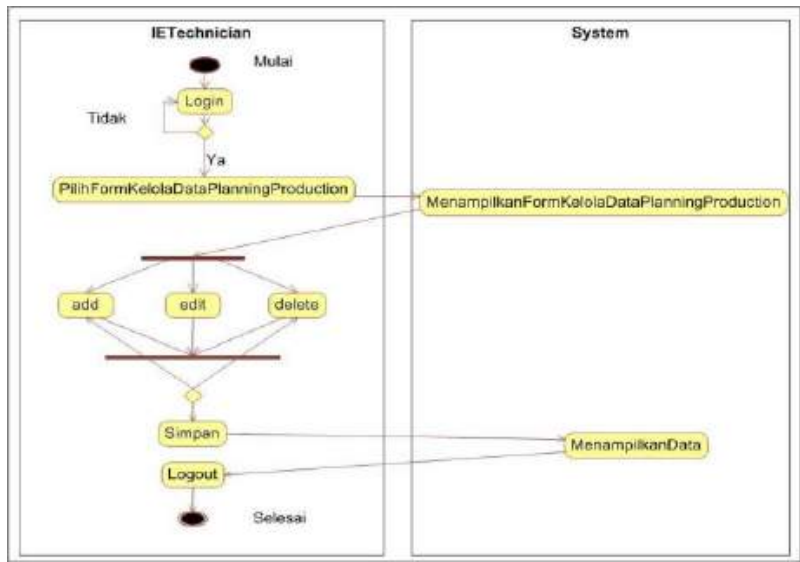

Desain Diagram Activity Supervisor Laporan Departemen 
Sistem Informasi

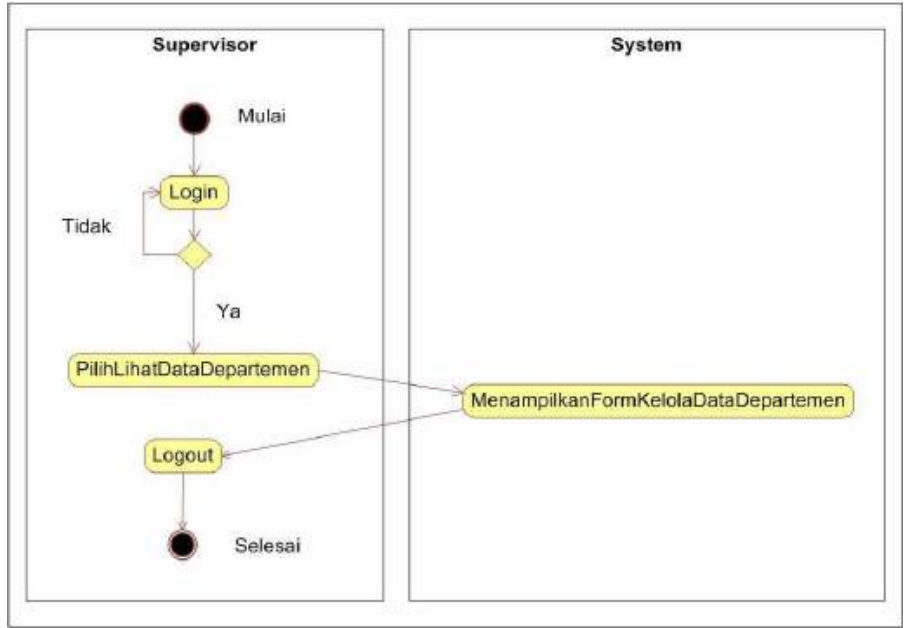

Desain Diagram Activity Supervisor Laporan Order.

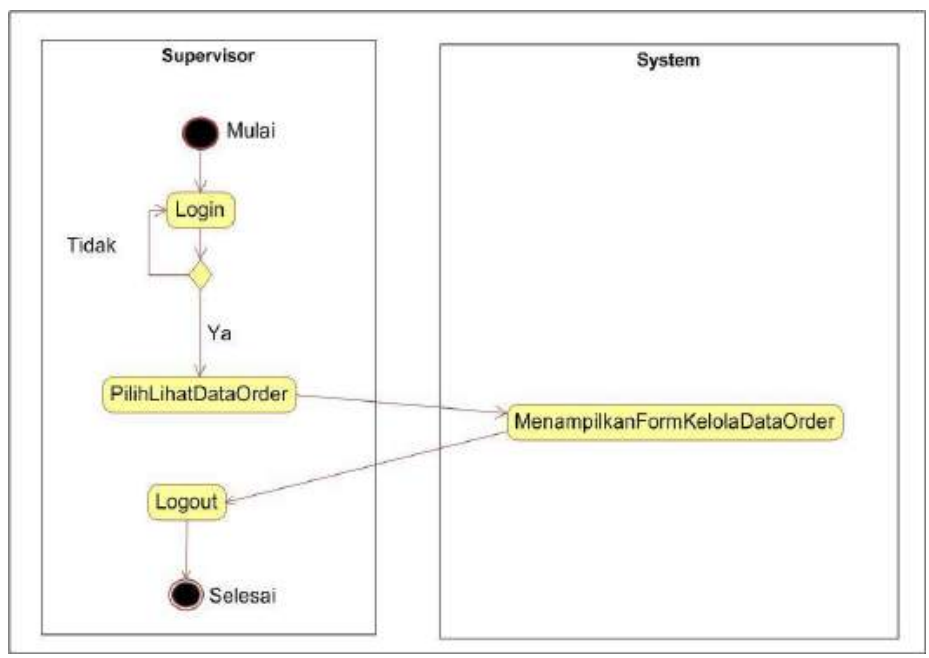

Desain Diagram Activity Supervisor Laporan Performance. 
Sistem Informasi

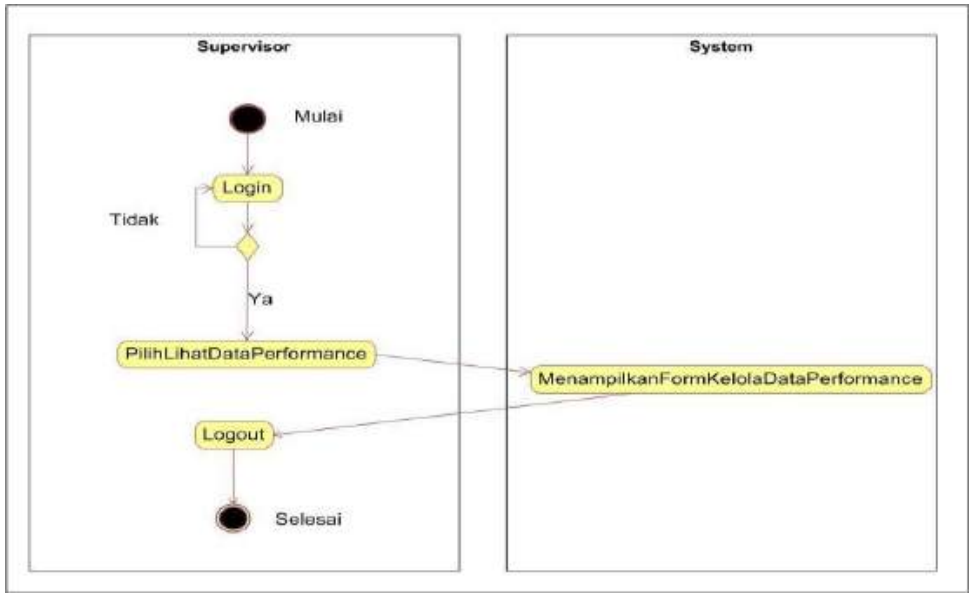

\section{Desain Diagram Activity Supervisor Laporan TimeStudy}

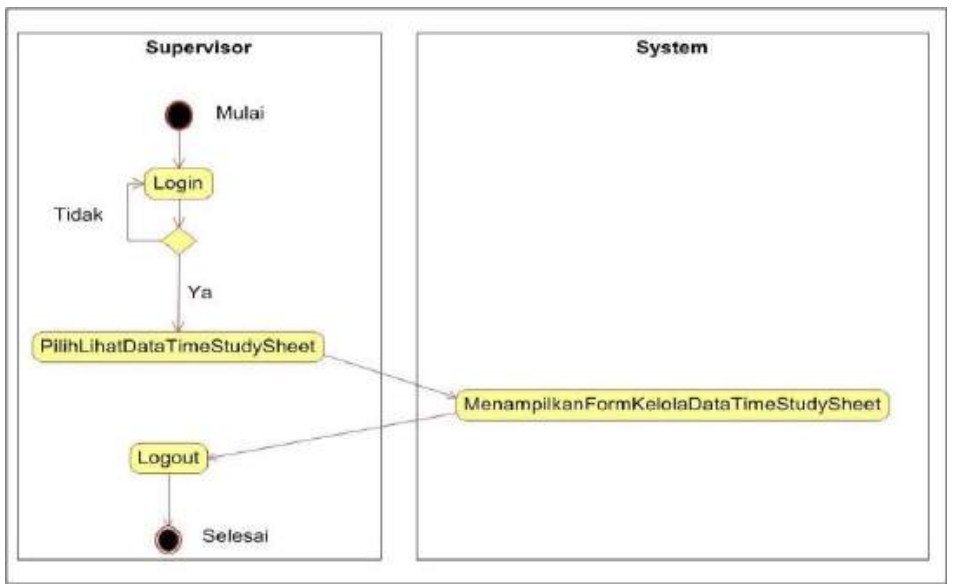

Desain Diagram Activity Supervisor Laporan Production Planning. 
Sistem Informasi

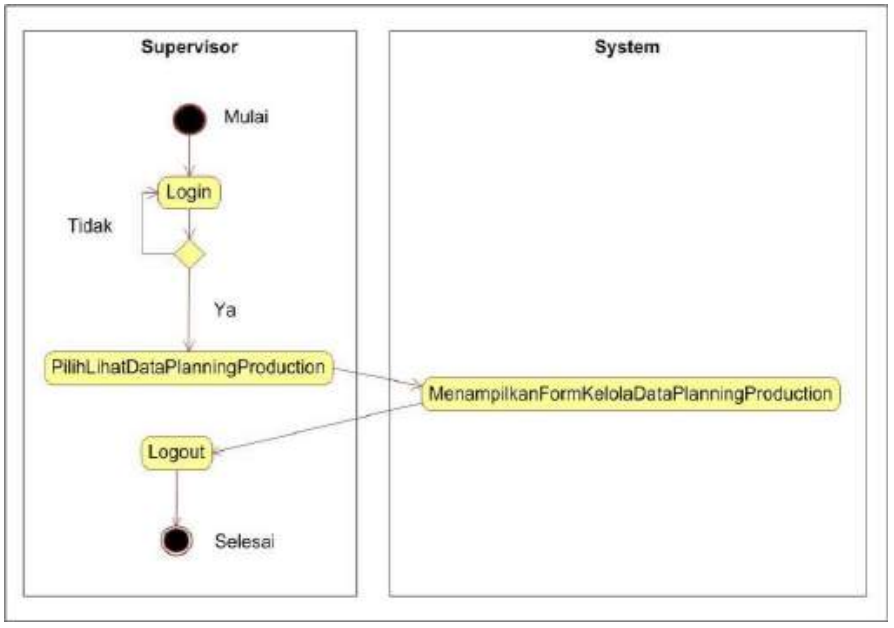

Desain Diagram Activity Supervisor Laporan UPH

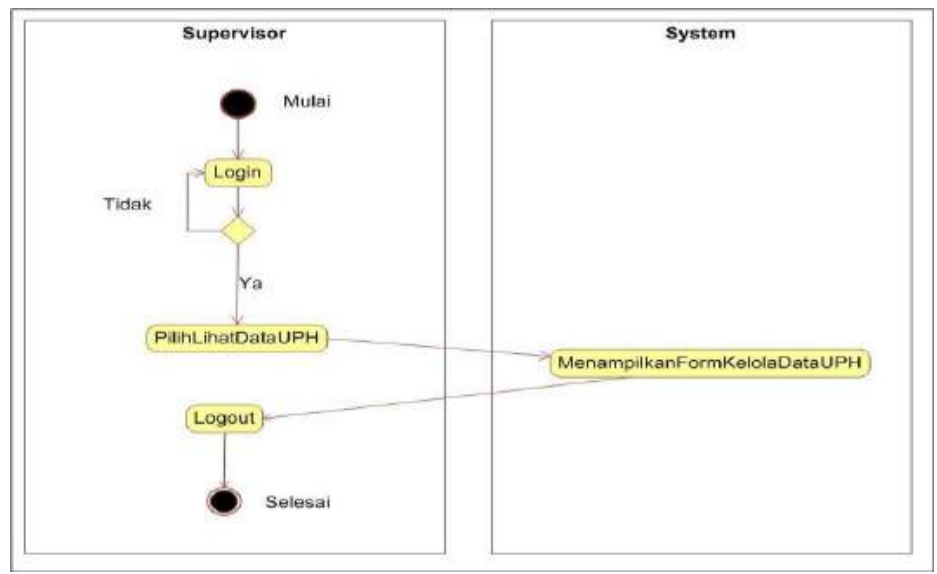

Desain Diagram Activity Pimpinan Laporan TimeStudy. 
Sistem Informasi

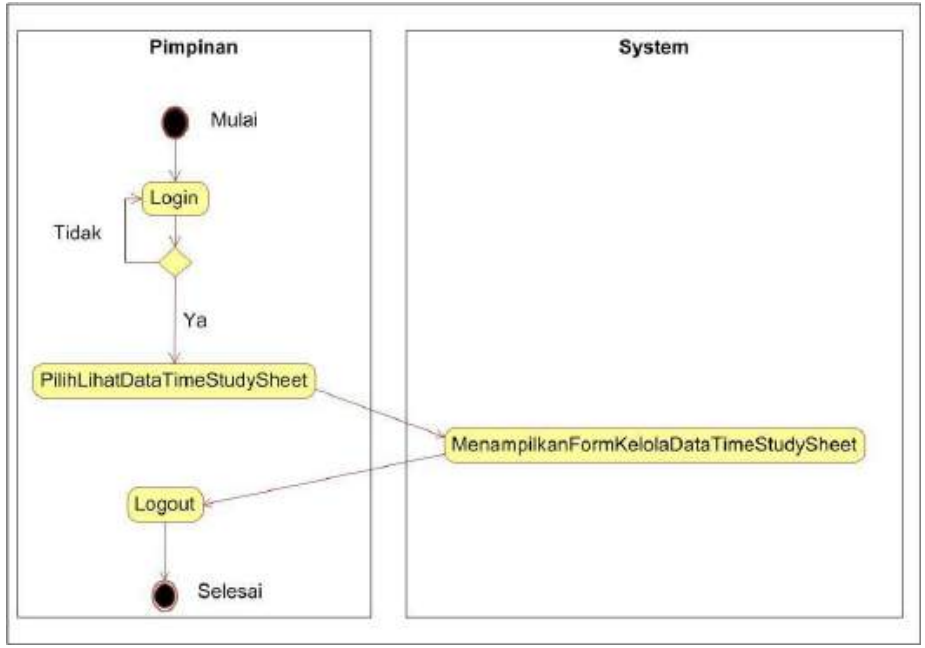

Desain Diagram Activity Pimpinan Laporan Production Planning.

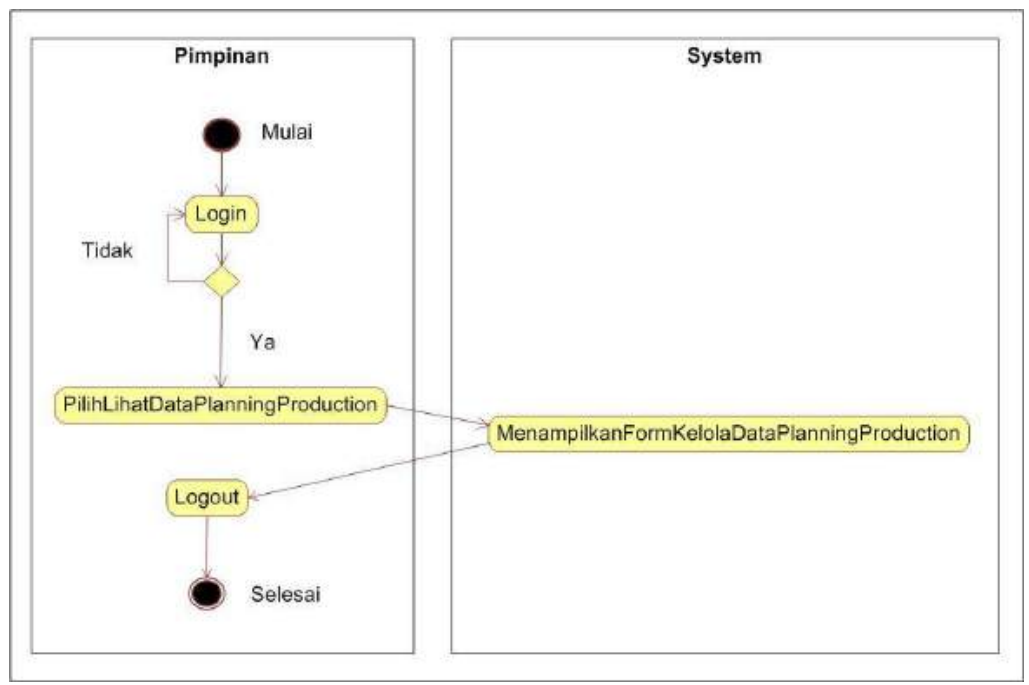

Desain Diagram Activity Pimpinan Laporan UPH. 
Sistem Informasi

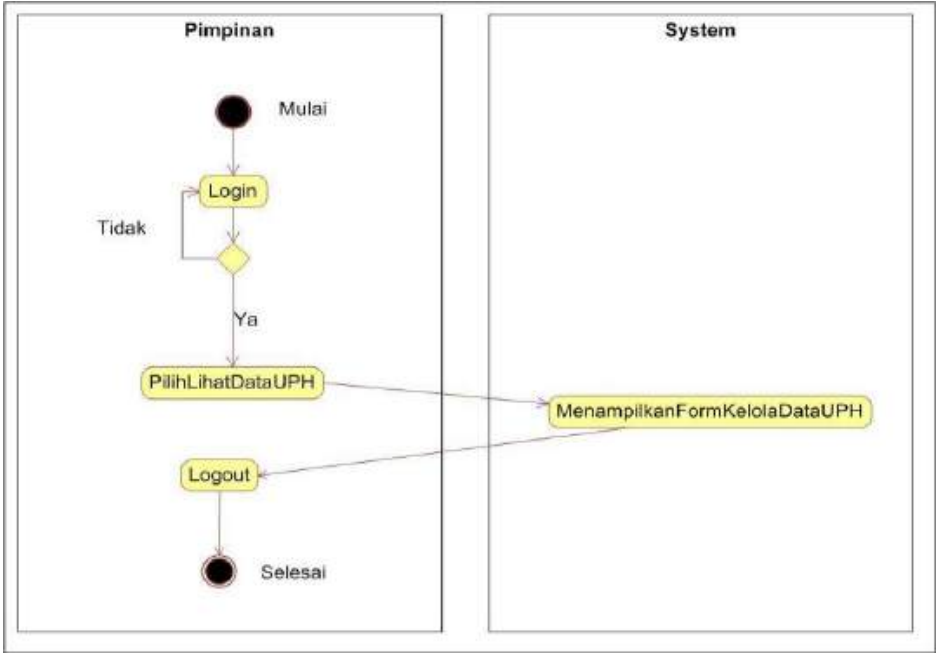

\section{Diagram Class}

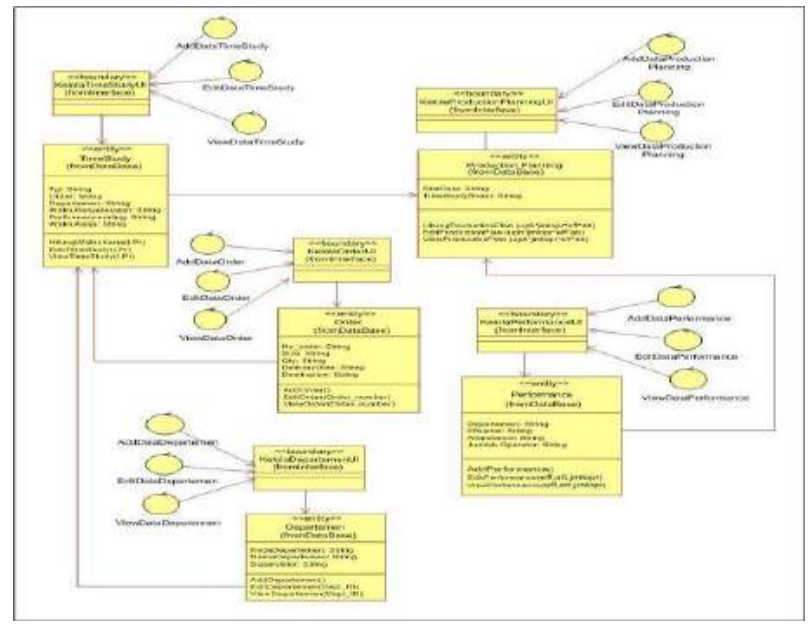

C. Evaluasi

1. Jelaskan macam-macam symbol dalam use case

2. Jelaskan macam-macam symbol dalam activity diagram 
3. Sebutkan macam-macam uml

4. Jelaskan manfaat class diagram

5. Apa fungsi sequence diagram

D. Referensi

Taufiq, R. (2013). Sistem Informasi Manajemen, Analisis dan Metode Pengembangan. Yogyakarta: Graha Ilmu. 


\section{BAB 7}

\section{DESAIN INTERFACE}

Dalam desain interface penulis membuat desain tentang rancangan sistem informasi yang nantinya akan digunakan oleh bagian IE. Desain Interface sangat diperlukan dalam suatu pembuatan sistem. Dengan adanya desain interface, diharapkan pengguna akan mudah memahami apa yang harus dilakukan dan menghindari terjadinya kebingungan saat menggunakan sistem.

Desain halaman dashboard

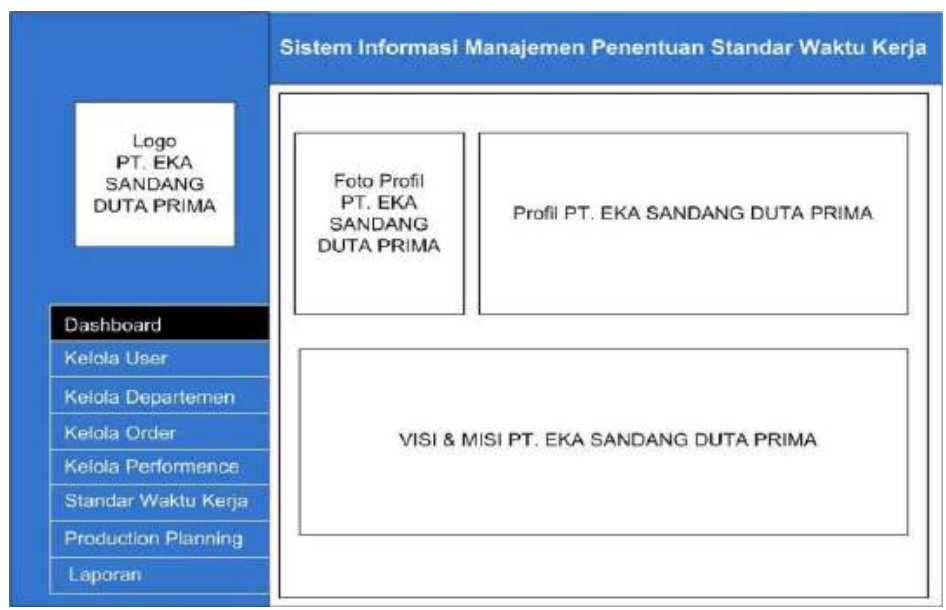

Desain form untuk halaman beranda yang berisikan profil perusahaan dan visi misi perusahaan. 
Desain halaman kelola data user

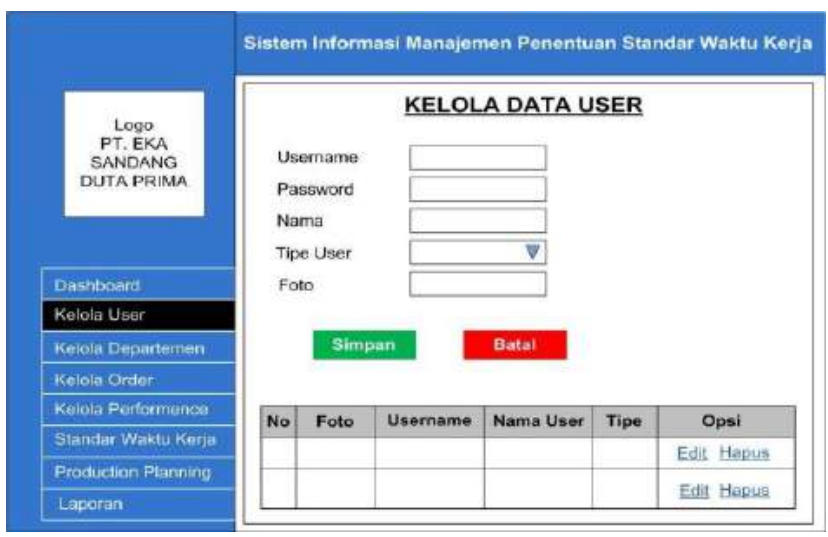

Desain form gambar diatas untuk data user, input data user, hapus dan edit data user.

Desain halaman kelola departemen

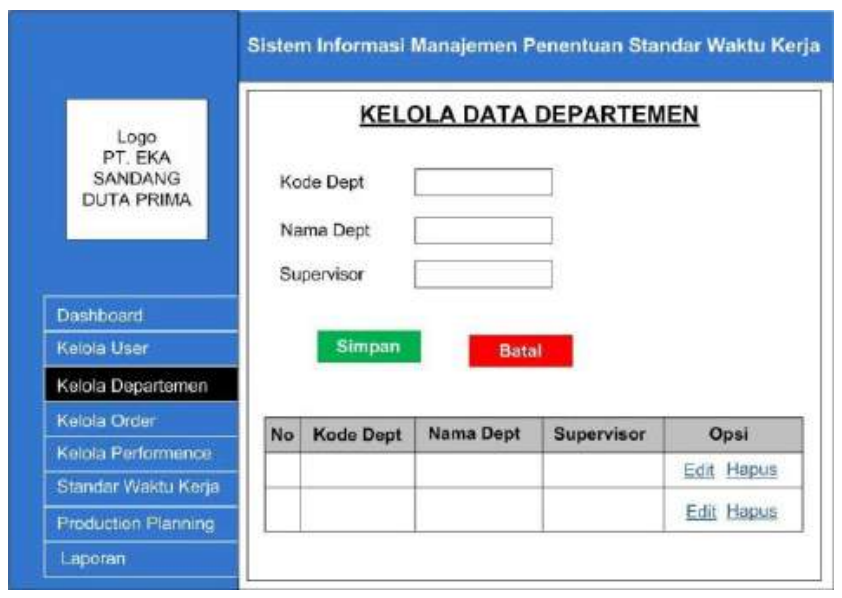

Desain halaman kelola data performance 


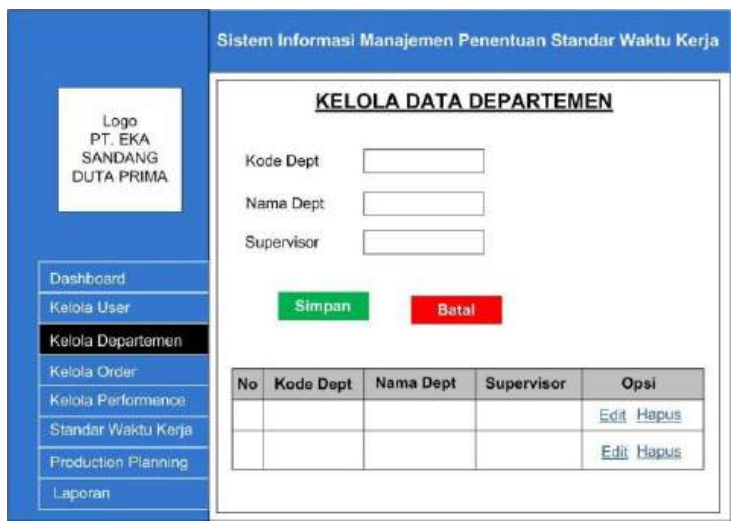

Desain form diatas untuk olah data departemen, input data departemen dan edit data departemen.

Desain halaman kelola data performance

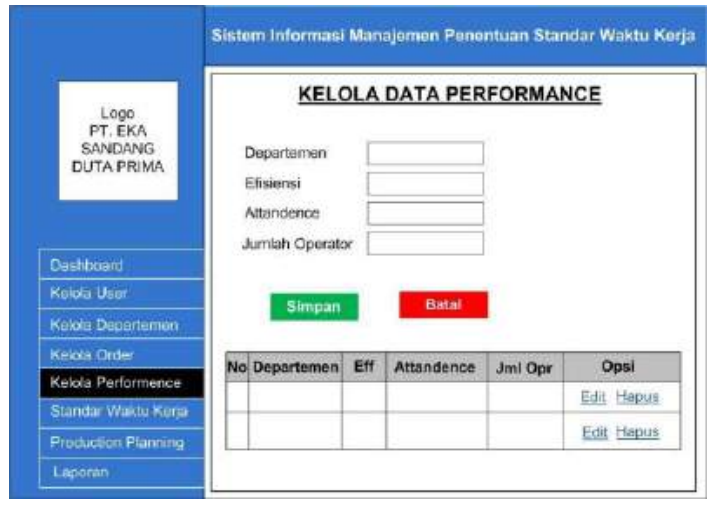

Desain halaman kelola data order 


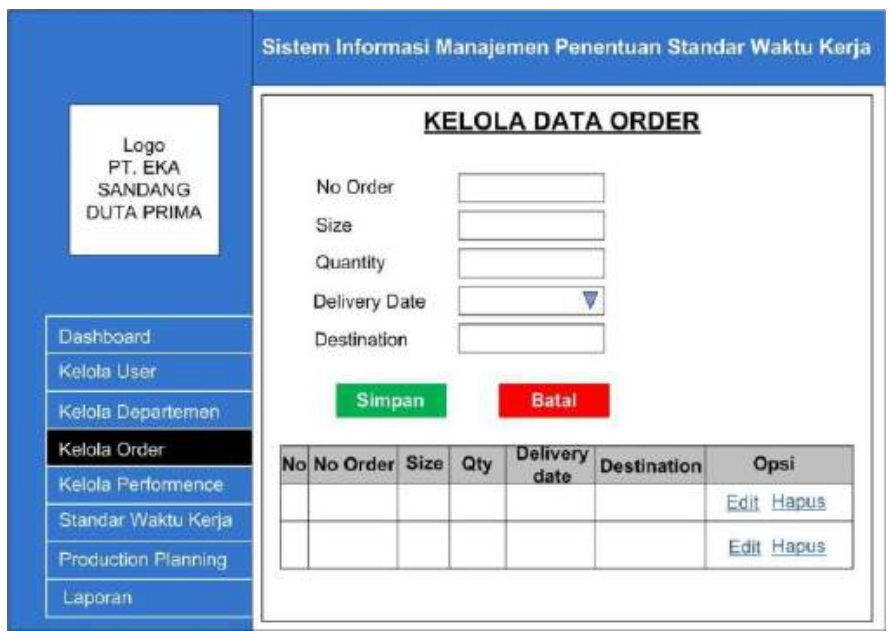

Desain halaman penentuan standar waktu kerja

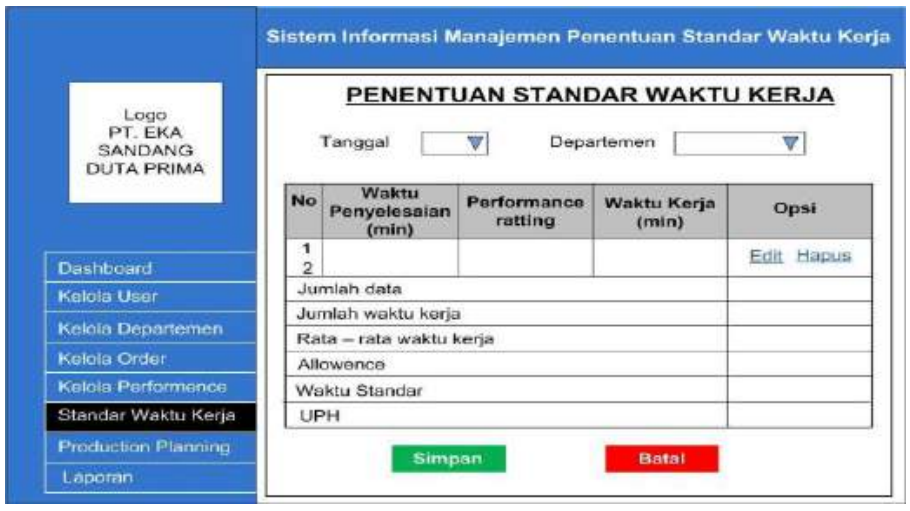

Desain halaman planning production 
Sistem Informasi

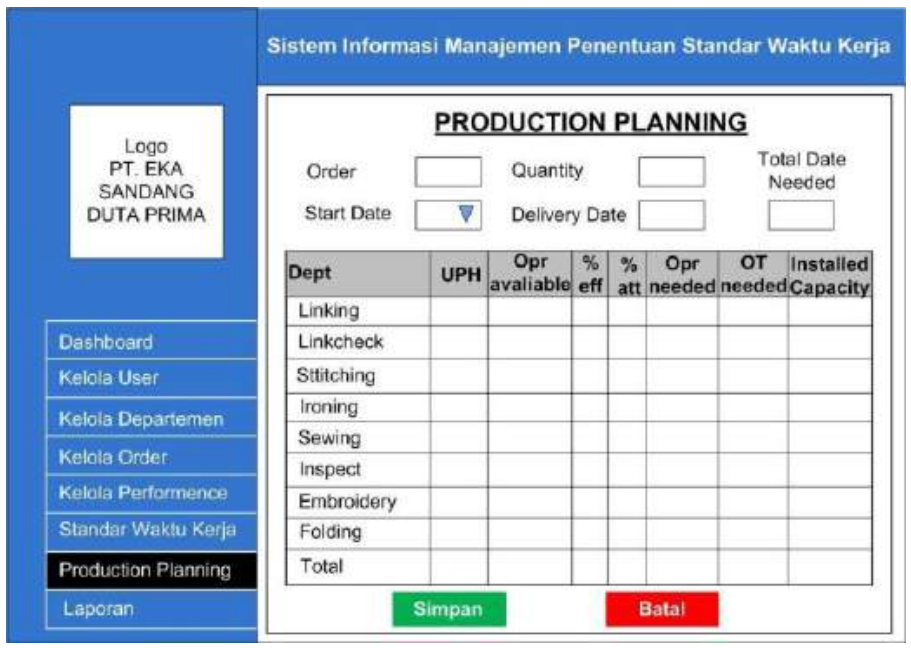

\section{Desain halaman laporan.}

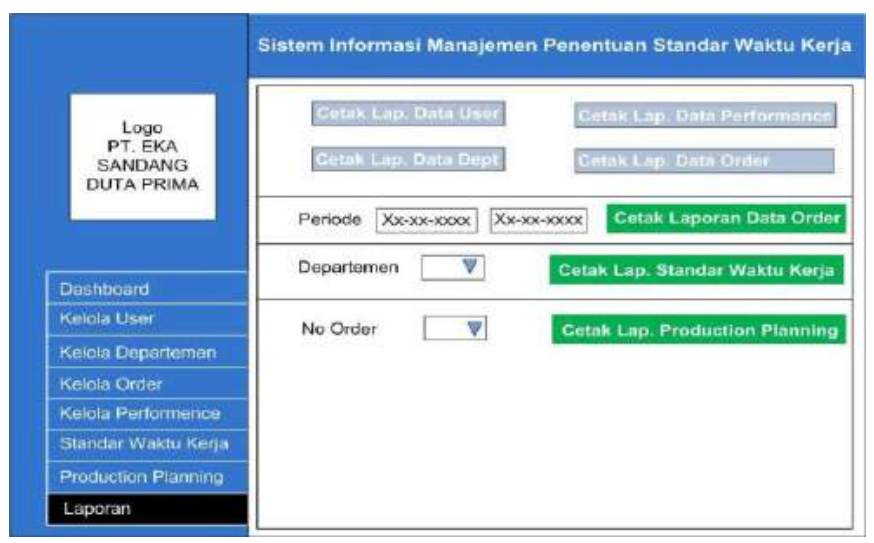


Sistem Informasi

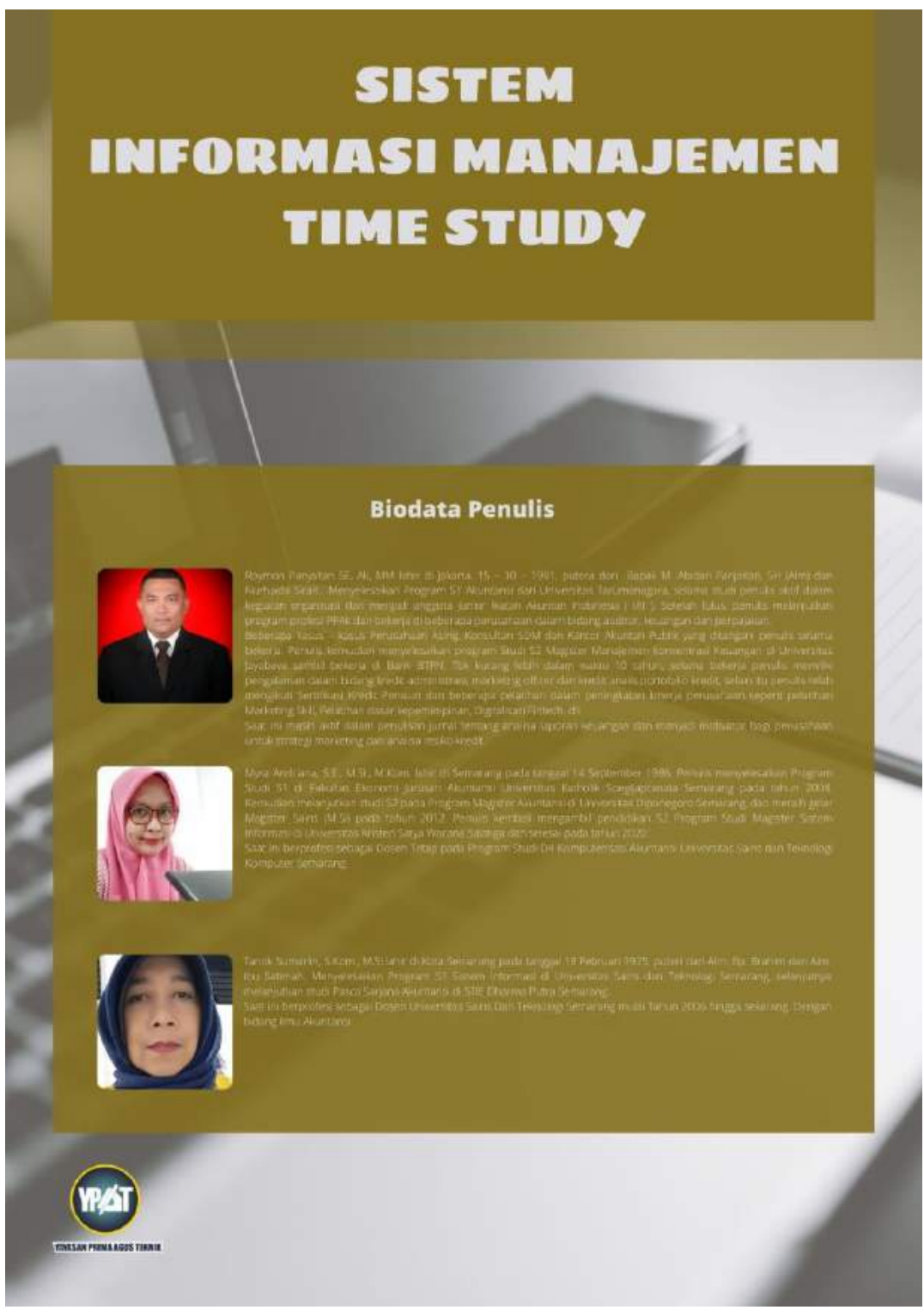


Sistem Informasi

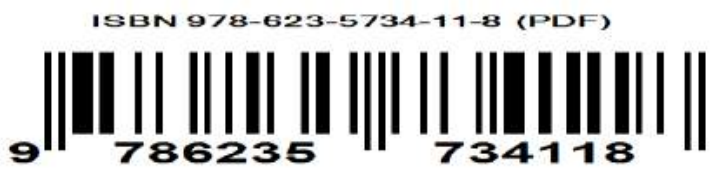


Sistem Informasi 